\title{
Direções e traçados da assistência hospitalar no Rio de Janeiro (1923-31) ${ }^{1}$
}

\author{
Directions in Hospital Assistance in \\ Rio de Janeiro (1923-31)
}

\section{Gisele Sanglard}

Historiadora, doutoranda no Programa de Pós-Graduação em História da Ciência da Saúde, COC/Fiocruz

sanglard@coc.fiocruz.br

Renato da Gama-Rosa Costa

Arquiteto e urbanista,

Departamento de Patrimônio

Histórico, COC/Fiocruz

Doutorando do Programa de

Pós-Graduação em Urbanismo

Prourb/FAU/UFRJ

rgrc@coc.fiocruz.br
SANGLARD, G. e COSTA, R. da Gama-Rosa: 'Direções e traçados da assistência hospitalar no Rio de Janeiro (1923-31)'. História, Ciências, Saúde-Manguinbos,

vol. 11(1): 107-41, jan.-abr. 2004.

Neste artigo discutimos as transformações pelas quais a saúde pública passa na cidade do Rio de Janeiro, na década de 1920, com a construção de três hospitais: o Gaffrée e Guinle, o do Câncer e o das Clínicas. Reforma sanitária e novos conceitos bacteriológicos misturam-se no projeto arquitetônico destes três hospitais, todos a cargo do engenheiro-arquiteto A. Porto d'Ave (1890-1952). Neste processo, destacam-se: a relação dos avanços da bacteriologia vis-à-vis com o desenvolvimento arquitetônico; o jogo de conceitos e concepções de bacteriologia; e os novos paradigmas da construção hospitalar. Estas discussões ocorrem em um momento crítico, em que a falta de leitos hospitalares na cidade é reconhecida, ao mesmo tempo que a adoção da tradicional estrutura pavilhonar estava em cheque frente os avanços introduzidos pela moderna arquitetura em monobloco.

PALAVRAS CHAVE: saúde pública, arquitetura hospitalar, Rio de Janeiro.

SANGLARD, G. e COSTA, R. da Gama-Rosa: 'Directions in Hospital Assistance in Rio de Janeiro (1923-31)'.

História, Ciências, Saúde-Manguinbos,

vol. 11(1): 107-41, Jan.-Apr. 2004.

Focusing on the construction of three bospitals (Gaffrée e Guinle, Hospital do Câncer, and Hospital das Clinicas), the article discusses transformations in Rio de Janeiro's public bealth sector during the 1920s. The three facilities' architectural design - all under the responsibility of architect and engineer A. Porto d'Ave (1890-1952) - reflected concerns of both sanitary reform and new concepts in bacteriology. Some points are particularly relevant: the relation between advances in bacteriology and architectural development; the concepts and conceptions of bacteriology, on the one hand, and new paradigms in hospital construction, on the other.

Discussions were taking place at a critical moment, when there was a shortage of hospital beds throughout Rio, at the same time that adoption of the traditional pavilion structure was bindered by the advances introduced by modern architecture in block.

KEYWORDS: public health, hospital, architecture, Rio de Janeiro 


\section{Alguns apontamentos acerca da arquitetura hospitalar na década de 1920 no Rio de Janeiro}

D oucos são os estudos acerca da história dos hospitais na cidade do 1 Rio de Janeiro, quer pela ótica da saúde pública, quer pela da arquitetura. Historiadores e pesquisadores têm se esforçado, por meio de estudos de casos, levantar essa história de uma forma mais pontual. ${ }^{2}$ É o que procuraremos fazer, ao analisar a construção dos hospitais que constituem o objeto de estudo no presente artigo — os hospitais da Fundação Gaffrée e Guinle, da Fundação Oswaldo Cruz ${ }^{3}$ e do Hospital das Clínicas. Na segunda metade da década de 1920 eram estes os hospitais em projeto e ou em construção no Rio de Janeiro, cidade onde os exemplos mais próximos de grandes hospitais haviam sido construídos, em sua grande maioria, no século anterior e representavam arquiteturas e práticas ultrapassadas. Pretende-se portanto, aqui, dar uma contribuição para a história da arquitetura hospitalar.

O primeiro aspecto importante é que todos foram projetados pelo engenheiro-arquiteto A. Porto d'Ave, fato que revela ser este profissional uma das maiores referências em arquitetura hospitalar da década de 1920 até meados da década de 1930, quando projetou e construiu o Hospital dos Servidores do Estado, em $1934 .{ }^{4} \mathrm{O}$ segundo aspecto é que esses hospitais representam a transição de um período da arquitetura hospitalar identificada com a tipologia pavilhonar européia (França, Inglaterra e Alemanha, basicamente) para aquele identificado com o modelo em bloco, representado pela arquitetura norte-americana. ${ }^{5} \mathrm{Em}$ terceiro lugar, esses hospitais denunciam que a influência da arquitetura hospitalar norte-americana se fez sentir entre nós muito antes do período identificado como moderno na arquitetura brasileira, que grosso modo se inicia na década de 1930 e vai até 1970, sendo as décadas de 1940 e 1950 as mais representativas desse estilo.

Os estudos que mostram a evolução tipológica da arquitetura hospitalar de um modo geral são menos raros e revelam que a história dos hospitais, contada desse ponto de vista, segue uma trilha já percorrida. Podemos citar de imediato o trabalho de Vicente Licínio Cardoso, ${ }^{6}$ em tese apresentada ao concurso para professor da Escola Politécnica, na cátedra de Arquitetura e Construção Civil. Em 1927, escreveu ele os Princípios geraes modernos de hygiene hospitalar. Ao longo do texto, traça a evolução do hospital moderno a partir de 1786 - com o surgimento do hospital pavilhonar na França, em reação aos tipos herdados da Idade Média e da Renascença — até os melhores exemplos de hospitais nos Estados Unidos, onde até hoje a arquitetura hospitalar se mostra mais complexa.

A publicação de estudos mais recentes procura esquematizar, por meio de imagens e exemplos representativos, cada fase da evolução do hospital, grosso modo dividida em Antiguidade, Idade Média, Renascença, Era Industrial e Pré-contemporânea. No Brasil, existe o 
trabalho de L. C. Miquelin (1992); nos Estados Unidos, o de Guenter B. Risse; e na Alemanha, o de Axel Hinrich Murken (1990), ${ }^{7}$ que contribuíram assim para o delineamento mais geral da história do hospital.

Nosso objetivo, neste artigo, é contribuir para essa história com a inclusão de estudos de casos e tornando-a mais contextualizada e próxima do nosso universo.

\section{O Hospital Gaffrée e Guinle}

A criação do Hospital Gaffrée e Guinle (Figura 1) para o combate à sífilis e às doenças venéreas está intimamente ligada à reforma sanitária levada a cabo por Carlos Chagas em 1920.

No final de 1919 o presidente Epitácio Pessoa criou por decreto o Departamento Nacional de Saúde Pública (DNSP), com o objetivo maior de coordenar as ações de saúde pública no país - de forma mais direta no Distrito Federal e, por meio de convênios, nos estados.

De todas as atribuições do recém-criado DNSP vale ressaltar que "O decreto que criara o DNSP abrira novas possibilidades para o combate à lepra e às doenças venéreas, com o estabelecimento de uma inspetoria específica vinculada diretamente à Diretoria Geral" (Hochman, 1998, p. 84) - a Inspetoria de Profilaxia da Lepra e das Doenças Venéreas, à qual coube também a profilaxia do câncer. Sua estrutura ficou assim definida: Eduardo Rabello, médico sifilógrafo, acadêmico e professor da Faculdade de Medicina, chefe da Inspetoria; Oscar da Silva Araújo, médico sifilógrafo, acadêmico, subinspetor; Mário Kroeff, médico sifilógrafo, inspetor sanitário; e mais uns poucos inspetores sanitários (Almanak Laemmert, 1921 e seguintes).

Carlos Chagas chamou a atenção, no relatório de 1922 do DNSP, publicado em anexo ao relatório do ministro João Luiz Alves em junho de 1923, que em outros países a profilaxia da sífilis era feita com muito empenho pelas autoridades, e era "o Brasil uma das poucas nações, de alto aperfeiçoamento médico, que não cuidara, ainda da campanha contra a sífilis, o que importava em uma das falhas mais notáveis de nossa administração sanitária..." (Brasil, 1923, p. 201), falha que a Inspetoria devia justamente corrigir.

O objetivo da Inspetoria era o combate de doenças que tinham recebido até então pouca atenção do governo: a lepra - à qual não se dedicara qualquer medida de higiene e que já tinha se tornado um problema em alguns estados, afetando até mesmo a imigração; e as doenças venéreas, sobretudo a sífilis, com suas conseqüências tanto para o indivíduo quanto para a degeneração da raça. "A Inspetoria foi criada, segundo a nova legislação, para orientar e dirigir a luta contra a lepra e as doenças venéreas em todo o território nacional e contra o câncer na capital do país" (Araújo, 1927, p. 196), lançando mão da propaganda e da educação higiênicas; e o tratamento de doentes em 
dispensários e/ou hospitais destinados especialmente para esse fim. Optou-se pela não-regulamentação da prostituição, mas especial atenção foi concedida às chamadas 'contagiantes', criando-se espaço exclusivo para elas.

Para a dotação de um hospital próprio, Chagas Filho dizia que seu pai, Carlos Chagas, “... deseja a criação de dispensários e solicita a participação da iniciativa privada, o que resultou na criação da Fundação Gaffrée Guinle" (Chagas Filho, 1993, p. 174).

Por outro lado, a carência de leitos hospitalares era latente na capital da República. Esta era uma preocupação que havia sido percebida, desde 1920, nas mensagens presidenciais, e Epitácio Pessoa chamava a atenção para o fato de que a reforma sanitária que estava se realizando deveria ser acompanhada por uma melhoria da rede hospitalar, sobretudo porque o hospital da Santa Casa da Misericórdia não comportava mais a quantidade de atendimentos requisitados. Reconhecia a deficiência e ressaltava a necessidade da construção de um hospital anexo à Faculdade de Medicina (Brasil, 1956, p. 107).

Foi nesse contexto de criação da Inspetoria de Profilaxia da Lepra e das Doenças Venéreas e de uma rede hospitalar deficitária que se criou a Fundação Gaffrée e Guinle, para realizar o que Epitácio Pessoa anunciara desde 1920: a construção de um hospital para venéreos, o que foi feito graças ao concurso da família Guinle.

A Fundação Gaffrée e Guinle foi criada em 20 de agosto de 1923, por iniciativa de Guilherme Guinle com o objetivo de perpetuar a memória de Eduardo Palassin Guinle, seu pai, e de seu padrinho, Candido Gaffrée. A familia Guinle e até mesmo Carlos Chagas sempre se referem ao papel encontrado junto aos documentos de Cândido Gaffrée, enunciando a vontade de legar uma determinada quantia de dinheiro para a construção de um hospital, intenção que foi redimensionada por Guilherme Guinle. ${ }^{8}$

Segundo a escritura da fundação, caberia à família Guinle construir e instalar um hospital para sífilis e doenças venéreas em terreno adquirido pela familia e, posteriormente, repassado para o patrimônio da fundação. O aparelhamento e a manutenção do hospital correriam às custas do governo federal. Caberia construir e instalar ambulatórios para diagnóstico e profilaxia da sífilis, em terrenos que seriam comprados pelo representante da família - Guilherme Guinle - em nome da fundação.

O hospital recebeu o nome de Hospital Gaffrée e Guinle, que jamais poderia ser trocado. Ficou acordado em 12 o número de ambulatórios a serem construídos pela fundação, dentre os quais quatro estavam ligados às instituições de saúde: Santa Casa da Misericórdia, Instituto de Proteção à Infância, anexo à Maternidade de Laranjeiras e nas dependências do hospital $\mathrm{N}^{\mathrm{a}} \mathrm{Sr}^{\mathrm{a}}$ das Dores (Cascadura). Outro foi instalado nas dependências da Casa da Moeda.

Percebe-se, entretanto, ao acompanhar a trajetória dessa instituição, que o acordo não fora muito rígido, pois em 1928 o arquiteto Porto 
d'Ave (1928, p. 8) anunciava que, naquele momento, a fundação contava com 15 ambulatórios prontos e em funcionamento; no ano seguinte era inaugurado o Hospital Gaffrée e Guinle, que contaria com um ambulatório, o 16a ambulatório da Fundação Gaffrée e Guinle.

Quanto ao custeio da fundação e de suas instalações, ficou definido que hospital e ambulatórios seriam financiados por verba do governo federal (DNSP); por doações, donativos e legados a ela destinados; e pelas taxas de serviço cobradas. A gratuidade seria somente para pessoas pobres. Com relação à administração, a fundação teria um Conselho Administrativo formado pelo diretor do DNSP, na época Carlos Chagas; por um especialista da Faculdade de Medicina, Eduardo Rabello; e por um representante da familia Guinle, o próprio Guilherme Guinle. Haveria também um Conselho Consultivo, formado por 17 membros, escolhidos entre pessoas de destaque na sociedade; dentre eles podem-se citar: Ataulpho Napolis de Paiva; Clementino Fraga; Felix Pacheco; Fernando Terra; Fernandes Figueira; Gabriel Ozório de Almeida; José Xavier Carvalho de Mendonça; Lineu de Paula Machado; Miguel Couto; Paulo de Frontin e Werneck Machado.

As realizações da fundação não tardam a aparecer: no primeiro relatório apresentado ao Conselho Consultivo, em 1925, seis dos 12 ambulatórios já estavam prontos e em funcionamento; eram eles: Engenho de Dentro (Figura 2), Paulo de Frontin, Andaraí (Figura 3), Pró-Matre, Hospício e Gávea. E as obras do hospital não tardariam a começar.

O hospital, cujo projeto era assinado pelo escritório do arquiteto Porto d'Ave (Porto d'Ave \& Haering), sob fiscalização e orientação dos médicos Eduardo Rabello e Gilberto de Moura Costa, foi inaugurado em $1^{\circ}$ de novembro de 1929 sem que todas as enfermarias estivessem equipadas, visto que faltaram os recursos governamentais destinados para tal fim, sendo seu primeiro diretor o dr. Gilberto de Moura Costa, que assumiu o posto em 1924.

O projeto do hospital contava com um prédio principal de quatro pavimentos, onde estavam localizados os diversos serviços e um ambulatório. Nele funcionavam os serviços de Pronto-Socorro, Vias Urinárias, Ginecologia, Obstetrícia, os serviços auxiliares ao ambulatório do hospital (laboratório, fisioterapia e raios X), Sífilis Visceral, Otorrinolaringologia e Oftalmologia, as salas de operação e Serviço de Mulheres Contagiantes. Além deles havia ainda: superintendência dos serviços administrativos; serviços de estatística e de enfermagem; renda da instituição; serviços sanitários; anfiteatro; rouparia; salão de honra; biblioteca; e museu. No campus foram projetados pavilhões especiais para abrigar: o Instituto de Pesquisa; o biotério; a capela — consagrada a Nâsr a da Conceição do Brasil; as oficinas de conservação; o dormitório dos empregados e a lavanderia (Figuras 4, 5 e 6).

O Instituto de Pesquisa foi pensado como uma homenagem clara à moderna bacteriologia, sobretudo se considerarmos o valor simbólico 
dos vitrais da escadaria principal, que representam os dois maiores nomes da bacteriologia mundial - Louis Pasteur e Robert Koch que ladeiam nosso grande bacteriologista Oswaldo Cruz, reforçando o cuidado com que o projeto foi pensado e desenvolvido (Figura 7). Vale ressaltar que coube a Gomes de Faria, pesquisador do Instituto Oswaldo Cruz, a orientação técnica desse Instituto de Pesquisa. Outra aproximação com o tipo de ciência desenvolvido em Manguinhos - pela Escola de Oswaldo Cruz - pode ser percebida no cuidado com que Gomes de Faria pensou nesse instituto: haveria laboratórios individuais, salas de anatomia patológica e também uma biblioteca própria, desvinculada do hospital.

Ainda na área do hospital, mas de forma independente, funcionava o laboratório de Álvaro Ozório de Almeida, custeado unicamente pela subvenção particular do próprio Guilherme Guinle. Neste laboratório Álvaro Ozório desenvolvia suas pesquisas de fisiologia, sobre o câncer e sobre a lepra, mantendo contato constante com o Instituto de Manguinhos e o Instituto da Indústria e Pesquisa Animal.

A melhor descrição do complexo hospitalar da Fundação Gaffrée e Guinle é dada por Eduardo Rabello (BANM, 27.9.1923, pp. 537-8) em discurso à Academia Nacional de Medicina. Apesar de longa, a citação permite perceber a dimensão dada ao projeto:

Vou expor à Academia o plano deste instituto. A fundação propõese desde logo auxiliar o governo na luta contra as doenças venéreas: a fundação de um hospital e de ambulatórios modelos. ...

O hospital não é somente um hospital, mas também um verdadeiro instituto, onde se estudarão e pesquisarão as doenças venéreas para o que se subdividirá em duas partes: uma, para o tratamento dos doentes, e outra, para as pesquisas.

$\mathrm{Na}$ parte das pesquisas haverá um verdadeiro instituto para o estudo da sífilis e das doenças venéreas. Nele se estudarão não só os melhores processos de diagnóstico dessas doenças, como os de tratamento. Além disso, procurar-se-á tratar da fabricação de remédios. Será um instituto de terapêutica experimental das doenças venéreas.

Conterá um serviço de ginecologia para atender aos casos de infecção ginecológica na mulher, e outro análogo de cirurgia para homens.

Além desses leitos, haverá mais cerca de 50 para prostitutas, que ficarão isoladas em um pequeno hospital à parte, completamente independente do resto do edifício, com logradouros próprios, jardins e mesmo quartos privativos para cada uma.

Para atender à questão da sífilis hereditária, será criada uma seção anexa à maternidade, para onde serão mandadas as gestantes que forem diagnosticadas como sifilíticas nos dispensários e não tiverem recursos para o tratamento. As crianças heredo-sifilíticas terão também uma creche anexa, onde permanecerão até os dois três anos. Essa creche será a base de um futuro asilo para o tratamento dos heredo-sifilíticos. 
Haverá ainda anexo um grande ambulatório, para todas as especialidades que tenham relação com as doenças venéreas, contendo consultórios para medicina, cirurgia, otorrinolaringologia, dermatologia, dentista, tudo enfim quanto for preciso para atender as diversas complicações e localizações da sífilis. Para ele irão os doentes que em outros dispensários tiverem necessidade de tratamento especial.

Além disso, atendendo à parte científica, será organizado um museu em uma das dependências do edifício; completar-se-á com uma biblioteca e sala de conferências.

Como se vê, e como eu disse, não é uma simples fundação de hospital, mas de uma grande instituição, que, uma vez levada a efeito, não terá par no mundo inteiro e colocará a profilaxia das doenças venéreas no Rio de Janeiro numa situação ímpar.

O entusiasmo de Eduardo Rabello pode ser compreendido ao lermos a descrição feita do hospital pelo próprio arquiteto responsável. Além da descrição espacial do terreno, Porto d'Ave chama a atenção para as transformações sofridas pelo projeto do hospital com a abertura de uma rua nos fundos do terreno - que recebeu o nome de avenida dos Trapicheiros, atual rua Silva Ramos - que o obrigou a criar uma fachada posterior, composta pela capela, pela entrada principal do Instituto de Pesquisa e pela casa do diretor-geral do hospital. No artigo que contém essas observações, Porto d'Ave também descreve as diversas seções e serviços do Hospital Gaffrée e Guinle.

Ao falar da Seção das Meretrizes, Porto d'Ave afirma e confirma a política levada a cabo pela Inspetoria de Profilaxia da Lepra e das Doenças Venéreas, em que se optava pela não-regulamentação da prostituição. Nessa passagem, Porto d'Ave (op. cit., p. 9) acabava por ressaltar todas as incertezas existentes sobre a melhor política a ser posta em prática no controle da sífilis, além de marcar o papel do hospital no combate ao mal venéreo:

Sendo impossível dentro da nossa constituição impor a obrigatoriedade do exame das meretrizes, como acontece em quase todos os países europeus, embora com resultados discutíveis, cogitou-se no plano deste hospital, de reservar-lhes acomodações especiais, dotadas de todo o conforto, de modo a atraí-las voluntariamente ao tratamento das doenças de que são as principais disseminadoras. Além das enfermarias para as indigentes, localizadas no andar térreo, para aquelas que desejarem maior conforto e possam pagá-lo, existem no 1o andar, na parte posterior, 28 quartos reservados de um leito, e quatro apartamentos de luxo, onde poderão ser tratadas com toda a reserva e conforto. As instalações destinadas a esta classe de doentes, embora no mesmo corpo do edifício principal, são inteiramente isoladas, com entrada e jardim próprios, atendendo assim aos preconceitos sociais e constituindo por assim dizer um hospital independente. 
A criação do complexo para o combate à sífilis - o hospital, o Instituto de Pesquisa e os ambulatórios — foi bem recebida tanto na imprensa médica quanto na cotidiana. Werneck Machado, em sessão da Academia Nacional de Medicina, pronunciou um discurso sobre a importância da criação da Fundação Gaffrée e Guinle, em que falava de sua experiência na Sociedade Brasileira de Profilaxia Moral e da iniciativa de Pizarro Gabizzo, de tentar construir um hospital antivenéreo no início do século; e solicitava um voto de louvor a Guilherme Guinle por sua iniciativa de patrocinar tal empreendimento. Deve-se chamar a atenção para o fato de que foi este discurso de Werneck Machado que ensejou a resposta de Eduardo Rabello, citada anteriormente. Na mesma sessão, Nascimento Gurgel, então presidente da academia, afirmava que a criação da fundação era "notícia altamente significativa".

Os periódicos médicos Arquivos Brasileiros de Medicina e Brasil Médico publicaram, em setembro de 1923, a íntegra dos termos constitutivos da Fundação Gaffrée e Guinle, em uma matéria que foi também publicada nos jornais Correio da Manhã, OJornal Jornal do Commercio. Isso mostra, de um lado, o valor que era dado à ação de Guilherme Guinle; de outro, a importância que o controle da sífilis tinha naquela sociedade. Em termos de comparação, pode-se falar que a importância da Fundação Gaffrée e Guinle é igual à da Liga Brasileira contra a Tuberculose - presença constante na grande imprensa.

A imprensa médica de grande circulação também publicava anualmente a movimentação dos ambulatórios da fundação, como forma de dar ciência à comunidade médica dos bons resultados colhidos e da boa aceitação da instituição por parte da sociedade.

\section{O Hospital do Câncer da Fundação Oswaldo Cruz}

A Fundação Oswaldo Cruz foi criada oficialmente em 25 de agosto de 1922, por iniciativa de um grupo de médicos, dentre eles João Pedroso, J. Pedro de Albuquerque, Leocádio Chaves, José Gomes de Faria, e por Waldemiro de Andrade, Oscar Meira, Bessa dos Santos, J. Cavalcanti, Guilherme Pereira, Partemiano Mendes e Alberto Lamartine, com objetivo de "determinar o modo mais eficaz de ser cultivada a memória de Oswaldo Cruz" (FCM/FOC, DAD/COC, s. d.). Na primeira sessão de trabalho, por iniciativa de Guilherme Guinle, ficou estabelecido que o objetivo da instituição seria a construção de um hospital dedicado ao estudo e ao tratamento do câncer. As despesas de construção e aparelhamento do hospital correriam por conta da família Guinle.

O presidente da fundação foi Salles Guerra, tendo como vicepresidente Guilherme Guinle; o conselho deliberativo era formado pelo procurador-geral da República Pires e Albuquerque, pelos senadores Alfredo Ellis e Felix Pacheco, pelo professor Miguel Couto, e pelos médicos João Marinho, Clementino Fraga (deputado à época), Mario Nazareth, Guilherme Guinle, João Carlos Rodrigues, Carlos Chagas, 
Visconde de Moraes, Salles Guerra, Belisário Penna, João Pedroso e Alberto Lamartine Teixeira Lopes.

Poucos dias depois, a 7 de setembro de 1922, Carlos Chagas (BVCC, set. 1922) anunciava na cerimônia de inauguração do Instituto Radium de Belo Horizonte:

... que não será em vão o grande exemplo civilizador da vossa iniciativa. Do altruísmo de brasileiros ilustres, que bem entenderam cultivar em obras de ciência a memória abençoada de mortos queridos, espero e me fio, seguro de que também na capital do país teremos em breve organizados os trabalhos sobre o câncer, em moldes amplos, facultados pela generosidade de moços de fortuna e de sentimento.

A documentação a respeito da instituição é falha, e pouco se pode aferir a partir das informações recebidas. A grande fonte para conhecêla é um documento escrito por Salles Guerra, que, porém, não consta a data. Entre as afirmativas que podem ser feitas, sabe-se que Guilherme Guinle contratou o arquiteto Porto d'Ave para elaborar a planta do hospital, que foi submetida à Comissão Técnica da Fundação, composta por Carlos Chagas, João Marinho e Eduardo Rebello.

Percebe-se, nesse ponto, uma incongruência entre a narrativa de Salles Guerra e a documentação existente: segundo carta do dr. Mauricio de Abreu (5.3.1924), 1ํ secretário da fundação, ao secretário-geral do Instituto Central dos Arquitetos do Brasil, foi proposto um concurso de projetos para o Hospital do Câncer. A seqüência da correspondência mostra que as plantas foram entregues a Guilherme Guinle, que as devolveu a Salles Guerra dizendo que a escolha caberia à própria fundação, e que seria ela a encaminhar o projeto vencedor à Prefeitura, para aprovação (10.1.1925). Teria esse concurso realmente se realizado? Teria Porto d'Ave ganho o concurso? Não podemos responder a essas perguntas, visto que não conseguimos localizar mais informação alguma a este respeito.

De qualquer forma, foi somente em novembro de 1926 que a pedra fundamental do hospital finalmente foi lançada, marcando o início das obras. O ato solene foi saudado da tribuna da Academia de Medicina por Eduardo Meirelles (BANM, 17.11.1926, p. 623).

Apesar de já ter conseguido um terreno no Cais do Porto, cuja venda foi autorizada por meio de requerimento ao Congresso Federal, o local escolhido para a instalação do hospital foi a região da Mangueira, suficientemente afastada do centro da cidade. Adquiriu-se, então, um terreno na rua Ana Nery, esquina com rua Visconde de Niterói. Posteriormente chegou-se a adquirir um outro terreno, que fazia fronteira com o anterior, visando melhorar a circulação do futuro hospital (FOC, 1924-1925, FCM/FOC, DAD/COC).

A Fundação Oswaldo Cruz, tal como a Fundação Gaffrée e Guinle, gozou de diversas isenções fiscais, tanto da municipalidade quanto do 
governo federal. Contudo, a maior parte dos donativos era recebida de particulares, entre eles: Orlando Rangel, José Antônio de Souza, o legado do ministro Murinelly, da sra. Carlos Chagas, de dona Eufrásia Teixeira Leite e da colônia portuguesa no Rio de Janeiro. Recebeu-se também donativo da comissão formada em 1917 na então Diretoria Geral da Saúde Pública, para a construção de um monumento a Oswaldo Cruz, instalado no pátio da diretoria. Ao encerramento da comissão, tendo encontrado saldo em sua conta corrente, decidiu-se repassá-lo à Fundação Oswaldo Cruz.

A construção do prédio que abrigaria o hospital começou lentamente, com o lançamento de sua pedra fundamental em 1926, e envolveu diversas disputas. Em 1928 a Alfândega cobrou as taxas de importação, que até então não estavam sendo cobradas. Aquele era um ano de mudança de governo, e a administração então eleita não honrou os acordos anteriores, rompendo-se assim a isenção alfandegária. A solução encontrada foi fazer a importação do material em nome da Fundação Gaffrée e Guinle, que ainda usufruía do benefício.

Pouco tempo depois, a construção foi paralisada por uma disputa entre o construtor Porto d'Ave e Arnaldo Guinle - responsável pelos negócios da família na ausência de seu irmão Guilherme, que na ocasião estava em viagem pela Europa — sobre a questão do pagamento dos operários, resultando na demissão do arquiteto. A obra só recomeçaria com a volta de Guilherme Guinle, algum tempo depois.

Outros entraves iriam atrasar ainda mais a conclusão das obras do hospital: com o passar do tempo, a técnica da pesquisa e do atendimento aos doentes havia mudado. Era preciso, então, adequar as plantas do hospital às novas necessidades, e uma comissão formada por pesquisadores do Instituto Oswaldo Cruz, em Manguinhos, foi convocada para opinar.

Do hospital há bem poucas referências. Como já foi salientado, o projeto e a construção ficaram a cargo de Porto d'Ave e contaram com a assessoria dos médicos Salles Guerra e João Pedroso. De iconografia só há as duas imagens publicadas na edição de 20 de janeiro de 1927 de OJornal (Figuras 8 e 9), e o único relato conhecido é dado por Vicente Licínio Cardoso (1927, pp. 196-7), que procurava ressaltar os pontos de convergência do projeto com o do Hospital Gaffrée e Guinle:

A obra compreenderá: um grande ambulatório; enfermarias para hospitalização, quer de indigentes, quer de doentes contribuintes, onde serão seguidos os variados processos terapêuticos em uso; instituto modelar, notavelmente amplo, em que serão feitas as mais variadas investigações e pesquisas, atendendo à importância magna que vão ter os estudos experimentais nesse instituto.

O projeto, também da lavra do arquiteto Porto d'Ave, foi organizado depois de dados e prescrições cuidadosamente oferecidos por profissionais de clínica e de laboratório, sendo seguida na elaboração 
geral - como fora feito para a FGG - uma orientação mista, norte-americana, quanto a composição geral dos edifícios em 'bloco', alemã, quanto aos detalhes de vários pontos.

Até 1935 as obras ainda não haviam sido concluídas, e Guilherme Guinle, pelas razões que explicara ${ }^{9}$ anteriormente a Salles Guerra afirmava, a 25 de setembro, que não iria mais custear a construção e o aparelhamento do Hospital do Câncer.

A 28 de junho de 1936, a Assembléia Geral da Fundação Oswaldo Cruz decidiu pela extinção do hospital, já que, sem o auxílio de Guilherme Guinle e sem apoio do governo federal, a conclusão das obras se tornara inviável.

Com a dissolução da fundação, seu patrimônio foi transferido para a Comissão do Monumento a Oswaldo Cruz, presidida, naquele momento, pelo médico Raul Leitão da Cunha. Desse patrimônio a Comissão retiraria o necessário para a conclusão das obras, e o excedente seria "... aplicado a uma bolsa de auxílio a estudantes de medicina pobres, que se tiveram distinguido por sua aplicação, e a prêmios ao autor de obras de medicina julgadas merecedoras dessa recompensa" (FCM/FOC, 27/07/36, cx. 1, maço 2).

Quanto à parte imóvel, esta seria fruto de discussões posteriores. Sabe-se, entretanto, que o prédio foi transferido para o governo, que lá instalou o Hospital Barata Ribeiro.

\section{O Hospital das Clínicas}

A construção de um hospital de clínicas era uma antiga demanda dos médicos ligados à Faculdade de Medicina, cuja clínica era realizada nas dependências da Santa Casa da Misericórdia. Por outro lado, as duas primeiras décadas do século XX pouca alteração trouxeram na oferta de leitos à população carente. A rede hospitalar pública ainda estava centrada no hospital da Santa Casa da Misericórdia e nas duas policlínicas - a Geral e a de Botafogo - , que ampliaram suas sedes ao longo do período: a nova sede da Policlínica Geral data de 1908 e a da Policlínica de Botafogo, de 1922.

O primeiro passo para minimizar a carência de leitos foi a transformação do antigo Asilo São Francisco de Assis em hospital, ligado ao DNSP, que começou a funcionar em 1922. Isso elevava a quatro o número de hospitais gerais e de atendimento público na capital da República.

Vicente Licínio Cardoso fez uma análise da real disponibilidade de leitos hospitalares na cidade do Rio de Janeiro, onde a Santa Casa, a maior rede hospitalar existente no país, oferecia 953 leitos - a grande maioria destinada à população carente. Vale lembrar que a Santa Casa aceitava público pagante, o que reduzia um pouco a disponibilidade para a população pobre da cidade. Os outros hospitais tinham em média de trezentos a seiscentos leitos (Cardoso, op. cit., pp. 193-4). 
Esses números dão uma idéia do impacto da construção de um hospital como o Gaffrée e Guinle, que destinava 320 leitos somente para doenças venéreas.

As mensagens presidenciais continuavam chamando a atenção para a precária situação hospitalar da capital do país, sobretudo para a insuficiência de hospitais gerais. No relatório de 1922 do DNSP, Carlos Chagas falava na criação de hospitais regionais e rurais para atender à campanha de saneamento rural (Brasil, 1923, p. 197). A preocupação existia, porém as medidas concretas para reverter o quadro eram poucas, quase nenhuma.

Talvez o maior indicativo de uma mudança na política pública voltada para assistência hospitalar tenha se dado em 1926, com a criação, durante a Presidência de Washington Luiz, da Assistência Hospitalar, órgão autônomo com relação ao DNSP, a quem competia a gestão dos hospitais São Francisco de Assis e Pedro II, bem como a fiscalização dos estabelecimentos hospitalares existentes na capital (Brasil, 1930, p. 69).

A direção do órgão foi entregue a João Marinho, professor da Faculdade de Medicina, e o Conselho Hospitalar era formado por Ataulfo de Paiva, Carlos Chagas, Guilherme Guinle, Clementino Fraga, Abreu Fialho e Miguel de Carvalho. A eles cabia o assessoramento do diretor no que tangia ao projeto mais ambicioso do órgão: a construção de um hospital para a Faculdade de Medicina, com capacidade para atender a 1.200 pessoas. A presença de Guilherme Guinle e Ataulfo de Paiva certamente deveu-se ao importante papel exercido por ambos na época: Guilherme Guinle, na condução das obras do Hospital Gaffrée e Guinle e do Hospital do Câncer; Ataulfo de Paiva, por suas ações frente à Fundação Liga Brasileira Contra a Tuberculose..$^{10}$

A gestão do projeto foi marcada por uma série de divergências: o projeto do Hospital das Clínicas da Faculdade de Medicina já estava escolhido quando João Marinho assumiu a direção do órgão. ${ }^{11}$ O projeto arquitetônico fora encomendado a Porto d'Ave — o mesmo arquiteto responsável pelos hospitais Gaffrée e Guinle e do Câncer — em 1925, e, aparentemente, João Marinho discordava tanto do projeto quanto do nome do construtor. ${ }^{12}$

Há uma série de coincidências nos projetos dos três hospitais, sobretudo entre os hospitais do Câncer e das Clínicas. Os membros do Conselho Hospitalar eram, em sua maioria, integrantes da Fundação Oswaldo Cruz (Carlos Chagas, Guilherme Guinle e Abreu Fialho). O próprio João Marinho, chefe da Assistência Hospitalar, dividira com Carlos Chagas e Eduardo Rabello a responsabilidade pela escolha do projeto do Hospital do Câncer.

Cronologicamente, a construção desses dois hospitais - o do Câncer e o das Clínicas - é simultânea. Levando-se em consideração que a Fundação Oswaldo Cruz foi marcada por uma série de imbróglios, fica a pergunta: até onde os problemas desta instituição não afetaram o desenvolvimento do projeto do Hospital das Clínicas. 
O segundo ponto é mais técnico: João Marinho aparentemente encantou-se com o projeto do Hospital das Clínicas de São Paulo, levado a cabo pelo médico Arnaldo Vieira de Carvalho, pelo trabalho da Fundação Rockefeller, sobretudo na construção do hospital de Rochester, em Nova York, e pela leitura do livro de Abraham Flexner, que lhe teria sido oferecido pelos médicos Oscar Clark e Osvino Pena. João Marinho chegou a viajar aos Estados Unidos, comissionado pela Assistência Hospitalar, para conhecer hospitais lá existentes, tendo sido recebido na Fundação Rockefeller por John Rockefeller. Da viajem saiu o esboço do que ele pensava para o Hospital das Clínicas da Faculdade de Medicina: o tratamento do doente, o ensino médico e a pesquisa científica (Marinho, 1931, p. 101). Aparentemente o grande problema percebido por João Marinho era que o projeto apresentado por Porto d'Ave era eminentemente pavilhonar. ${ }^{13}$

Neste ponto vale recorrer a Vicente Licínio Cardoso (op. cit., p. 193), chamado a opinar sobre o projeto do Hospital das Clínicas, na condição de especialista da Escola Politécnica em arquitetura hospitalar. Diz ele:

O sistema adotado foi o pavilhonar em bloco, com ligações por galerias subterrâneas, havendo, além dos edifícios gerais ou especiais requeridos pelo conjunto, dez pavilhões de clínicas com cinco pavimentos cada um, ocupados por enfermarias e seus respectivos anexos.

Não examinei o projeto de autoria do arquiteto Porto d'Ave, realizado de acordo com instruções da Assistência Hospitalar e de alguns professores da Faculdade de Medicina. Conheço, pois, apenas as linhas gerais do grande plano elaborado - que não veio aliás a público - , sem que agora me pronuncie sobre uma série de problemas que lhe são correlatos (mudança da Faculdade, centralização hospitalar etc.). Todavia, devo consignar aqui neste trabalho a boa impressão recebida do fato de fugir o projeto ao rigorismo dos projetos hospitalares europeus, compreendida que está a influência da escola norte-americana na aceitação de pavilhões com cinco pavimentos.

Apesar de defender abertamente o modelo de arquitetura hospitalar norte-americana, Vicente Licínio Cardoso não desmerecia o projeto de Porto d'Ave para o Hospital das Clínicas, sobretudo por ele não ser totalmente europeu, ou pavilhonar, mas misto, como os outros dois projetos do mesmo arquiteto. Pode-se mesmo falar que Porto d'Ave projetou o Hospital das Clínicas a partir de vários hospitais específicos, criando quase uma cidade-hospital (Figura 10), em que cada uma das especialidades médicas teria seu próprio pavilhão, interligando-se uns com os outros, tanto pela parte externa quanto pelos corredores subterrâneos. Uma das críticas de João Marinho ao projeto era a grande distância a ser percorrida entre um pavilhão e outro, distância que seria minimizada em um hospital em bloco (Marinho, op. cit.). 
Hoje em dia não resta dúvida sobre a maior praticidade do monobloco, em comparação com os pavilhões. Mas as dúvidas permanecem quanto às críticas de João Marinho: até onde não eram motivadas por outras razões que não somente as técnicas, mesmo porque, tanto ele quanto Vicente Licínio Cardoso citavam o exemplo belga de construção de um grande hospital geral e pavilhonar, tal como o primeiramente proposto por Porto d'Ave.

A divergência foi bem acentuada, de sorte que foram apresentados mais cinco projetos, sendo mais dois de Porto d'Ave e um do engenheiro Armando Augusto de Godoy. ${ }^{14}$ Acreditamos que tenha havido um certo favorecimento de Porto d'Ave, pois seu terceiro projeto — já em monobloco - foi aceito pelo Conselho Hospitalar. Iniciaram-se as obras imediatamente, apesar da discordância explícita de João Marinho.

Outras questões também foram levantadas por João Marinho: a localização escolhida - a região da Mangueira, próximo a rua São Francisco Xavier - e a localização da maternidade, dentro ou fora do prédio. Para Vicente Licínio Cardoso, com as modernas concepções de higiene, pautadas na assepsia, o hospital moderno deixava de ser um problema, podendo localizar-se em qualquer ponto da cidade. Este era um dos méritos que ele percebia na concepção do Hospital Gaffrée e Guinle, construído na Tijuca, bairro populoso da cidade do Rio de Janeiro.

Quanto à questão da maternidade, João Marinho afirmava que, em São Paulo, a maternidade estava dentro do hospital e não havia, portanto, motivo para localizá-lo fora do corpo do hospital no Rio de Janeiro. Vicente Licínio Cardoso chamava a atenção de que a maternidade era o grande 'calcanhar de Aquiles' da arquitetura norte-americana, pois era onde aconteciam os maiores focos de contaminação, justamente pela má localização. Fica novamente a questão de até onde as questões levantadas por João Marinho eram decorrentes de duas visões de mundo diferentes, e até onde se pautavam em questões de outra ordem. O certo é que no último projeto de Porto d'Ave a maternidade estava localizada à parte (Figura 11).

Chagas Filho, ao comentar a passagem de seu pai pelo Conselho Hospitalar, afirma que Carlos Chagas defendeu muito a idéia da construção do Hospital das Clínicas. E complementa: "Divergências de grande porte se estabeleceram entre o diretor-geral do Ministério da Justiça e Negócios Interiores e João Marinho...” (Chagas Filho, op. cit., p. 254), divergências técnicas, administrativas e certamente pessoais João Marinho se ressentia com o fato de que Porto d'Ave tinha acesso fácil ao ministro da Justiça e Negócios Interiores, Vianna do Castelo, e ao presidente Washington Luiz, que era amigo do construtor, e ambos freqüentadores do Automóvel Clube do Brasil e do Clube dos Bandeirantes.

O certo é que em 1931 as obras foram embargadas pelo presidente Getúlio Vargas e passaram por uma sindicância interna, da qual temos a versão de João Marinho, publicada em 1931 sob o título de Ocasião 
perdida. As obras jamais foram retomadas, e o esqueleto do que seria o hospital acabou aproveitado para a instalação do campus Maracanã da Universidade do Estado do Rio de Janeiro (Chagas Filho, op. cit.).

\section{Porto d'Ave: engenheiro, arquiteto, construtor}

Na literatura sobre o tema, o engenheiro-arquiteto Porto d'Ave está citado como construtor e projetista do Gaffrée e Guinle no Guia da arquitetura eclética no Rio de Janeiro (Czajkowski, 2000), juntamente com o engenheiro Haering ${ }^{15}$, e no livro História da engenharia no Brasil (Telles, 1984), no qual Porto d'Ave aparece duas vezes, como integrante da primeira diretoria da Associação Brasileira do Concreto e como autor do projeto, não realizado, do trecho fluminense da estrada Rio-São Paulo, representando o Automóvel Clube do Brasil, do qual era diretor. D'Ave aparece ainda - e de uma forma agora para nós mais óbvia - no livro de Licínio Cardoso, que o confirma como arquiteto dos hospitais que estamos estudando e como um dos maiores nomes da área na época de publicação do volume.

Adelstano Soares de Mattos Porto d'Ave (Figura 12) nasceu no Rio de Janeiro, no dia 6 de março de 1890, e faleceu na mesma cidade em 1952. Casou-se com Hilda de Oliveira Rocha, com quem teve seis filhos. Esse descendente de pai português e mãe brasileira — seu pai recebera o título de visconde de Nㅗ Sra de Porto d'Ave do rei de Portugal, dom Carlos, em $1897^{16}$ - freqüentou os melhores colégios existentes, inclusive o tradicional Colégio Anchieta, em Nova Friburgo, renomado centro educador onde estudou boa parte dos filhos da aristocracia. Cursou a Escola Politécnica entre 1911 e 1918, formando-se engenheirogeógrafo $^{17}$ em 1919, e traba-lhando como arquiteto e construtor.

No início da década de 1920, pouco tempo depois de formado e, ao que tudo indica, por convite de Guilherme Guinle, tornou-se responsável pelo projeto do Hospital Gaffrée e Guinle. Em 1924, novamente por intermédio de Guinle, fez o projeto do Hospital e do Instituto do Câncer, da Fundação Oswaldo Cruz. A partir desse apoio inicial de Guilherme Guinle, Porto d'Ave especializou-se em arquitetura hospitalar. Ainda na década de 1920 desenvolveu o projeto do Sanatório Santa Clara, em Campos do Jordão, São Paulo. No momento da construção dos hospitais Gaffrée e Guinle e do Câncer, estava registrado como construtor (Almanak Laemmert, 1927) e seu escritório funcionava na rua Buenos Aires, 54, $2^{\circ}$ andar.

A relação de Porto d'Ave com a família Guinle é bem próxima: sua cunhada Gilda, irmã de Hilda, casou-se com Carlos Guinle, irmão de Guilherme. Todos participavam de alguns clubes, como o Jockey Club e o Automóvel Clube do Brasil. Sem dúvida pode-se afirmar que a vida do arquiteto esteve intimamente ligada aos Guinle: primeiro a Guilherme, a quem se pode chamar de seu padrinho profissional - pelo menos nos projetos dos três primeiros hospitais Porto d'Ave contou com o 
apoio e a indicação de Guilherme; e, em segundo lugar, a seu concunhado Carlos - pois sua residência na esquina das ruas Sorocaba com São Clemente, em Botafogo, ainda pertence à família de Carlos Guinle.

As múltiplas atividades dos engenheiros eram prática comum naquelas primeiras décadas do século XX. Eles atuavam em arquitetura, nos seus mais variados programas, em engenharia, nas suas mais diversas especialidades, e em construção. Interessavam-se por questões de higiene das cidades, aberturas de estradas, descoberta de novos materiais de construção, como o concreto, participavam da vida política etc. (Ver nota 16.)

Como exemplo dessa diversificação de atividades pode-se mencionar a participação de Porto d'Ave no Clube dos Bandeirantes, do qual chegou a ser presidente. O clube reunia intelectuais, empresários, militares e grandes nomes da política dos anos 1920, como o ministro Getúlio Vargas, os ministros da Guerra e da Aviação e o próprio presidente Washington Luiz. O Clube dos Bandeirantes era uma entidade cívico-cultural que tinha na revista $A$ Bandeira o porta-voz de seus projetos e propostas, visando a questão da defesa nacional, o crescimento industrial, a modernização agrícola, o saneamento e a educação. A revista tinha duas seções 'A Terra e o Homem' e 'A Defesa Naciona'; às questões políticas juntavam-se matérias sobre automobilismo, esporte, turismo e assuntos que reforçassem as idéias de modernização e prosperidade, no interior das quais a integração nacional era o ponto importante. Nesse sentido, não é de estranhar que temas diretamente ligados à questão da comunicação fossem extremamente caros a esse grupo, tais como a construção de estradas, aviação e telégrafo (Carvalho, 1998, p. 88-92).

Por fim cabe ressaltar que a feição de arquiteto de Porto d'Ave desenvolveu-se pouco tempo depois de sua colação de grau, em março de 1919, com o projeto do Hospital Gaffrée e Guinle, no início dos anos de 1920, juntamente com Haering — apesar de anunciadas desde 1920, as obras iniciaram-se em 1924. Isso mostra que bem cedo o engenheirogeógrafo já estava realizando projetos arquitetônicos de grande vulto: primeiro o Hospital Gaffrée e Guinle e depois, em 1926, os hospitais do Câncer e das Clínicas. Sem dúvida sua relação com a família Guinle rendeu-lhe bons frutos, mas fica a pergunta: até que ponto esse apadrinhamento explícito de Guilherme Guinle não gerou alguns dos problemas pelos quais os projetos dos hospitais do Câncer e das Clínicas passaram?

\section{A arquitetura hospitalar e os projetos de Porto d'Ave}

No livro de Vicente Licínio Cardoso (op. cit.) são citados os marcos da arquitetura hospitalar. Para nós é importante acompanhar essa evolução, pois os hospitais servem como balizas para se entender a arquitetura de Porto d'Ave. Cardoso começava a traçar a constituição 
da moderna arquitetura hospitalar pelo estabelecimento, em 1786, por parte da Academia Francesa, de novos programas hospitalares visando sanar as precárias condições de higiene deixadas pelo modelo de antigos casarões, herdado da Idade Média e da Renascença. Demoraria ainda algumas décadas até que a reconstrução do Hotel de Dieu, de Paris,$^{18} \mathrm{em} 1864$, se tornasse o novo paradigma da construção hospitalar, com sua tipologia de pavilhões de isolamento. Mas os hospitais franceses tinham sobretudo se transformado em verdadeiras instituições médicas, e é em seus limites que as três bases da moderna medicina iriam encontrar espaço para se desenvolver: o exame clínico, o estudo da anatomia patológica e a estatística. ${ }^{19}$

Entre 1867 e 1870 surgiram, na Inglaterra, os hospitais de isolamento construídos pelo Metropolitan Asylum Board, em torno dos núcleos urbanos, inaugurando uma prática de descentralização e especialização dos hospitais, em que as doenças eram separadas por tipo, minimizandose os processos de contágio. Desse período até 1900 começou a se especializar na Inglaterra a prática da enfermagem, iniciada por Florence Nightingale durante a Guerra da Criméia (1854-56), aprimorando o tratamento das moléstias contagiosas e contribuindo, aliada à prática de especialização dos hospitais, para a redução drástica da mortalidade decorrente das epidemias.

Em 1900 foram inaugurados, na França, dois pavilhões do Hospital Pasteur, dando aos franceses a orientação geral moderna da hospitalização de doenças contagiosas (Cardoso, op. cit., p. 125). As descobertas de Pasteur, na segunda metade do século XIX, revolucionaram os conhecimentos sobre a transmissibilidade das doenças, com a construção da idéia de agente etiológico, o micróbio, que veio afetar não só as velhas idéias sobre as moléstias mas também a questão da hospitalização. Foi somente nas primeiras décadas do século XX, contudo, que o hospital passou a não representar mais aquele lugar de foco de doença e que precisava ser isolado da cidade.

Entre 1880 e 1914, as grandes organizações hospitalares surgidas em Hamburgo, Munique, Nurenberg e Berlim, na Alemanha, passaram a se preocupar com questões relativas aos grandes cuidados técnicos na execução, criação, ampliação e especialização dos hospitais, fazendo com que este país se tornasse o líder em assuntos hospitalares, segundo Cardoso.

Nos exemplos alemães, Cardoso citava o Hospital de Berlim, construído entre 1868 e 1874, como o primeiro hospital pavilhonar da Alemanha; e o de Eppendorf, construído entre 1884 e 1888, tido à época como o mais importante hospital do mundo. Eles representavam ainda o início da construção dos grandes hospitais gerais (com mais de dois leitos) e o início da sistematização do uso do microscópio, passando o hospital a realizar pesquisas e estudos clínicos. Esses grandes hospitais seriam separados dos menores, que passariam a cuidar de serviços especializados, como maternidades, clínicas pediátricas e neurológicas, sanatórios, 
preventórios para tuberculosos, estabelecimentos fisicoterápicos, asilos, dispensários, creches, policlínicas etc.

A evolução hospitalar na Europa, por meio sobretudo dos exemplos franceses, ingleses e alemães, passou a demonstrar que os hospitais não eram mais tidos como edifícios de reclusão e tratamento de doentes terminais, ou mesmo como 'refúgio das misérias humanas', como o hospital medieval, mas sim como centros de defesa social (Cardoso, op. cit., p. 118).

Mas foi preciso que houvesse também uma mudança no conceito de propagação da doença, para que ocorressem transformações na estrutura dos hospitais. Na época dos hospitais pavilhonares, acreditavase que o contágio vinha pelo ar, o que justificava a tipologia em pavilhões de isolamento. Com o avanço do campo da profilaxia, passouse a acreditar que os hospitais não eram mais aqueles ambientes perigosos e propícios a infecções externas e internas. Bastava que houvesse preocupação com uma enfermaria asséptica, não muito grande, com oito, dez ou 16 leitos, bem ventilada e com boa iluminação natural, separando-se os doentes às vezes apenas com simples móveis em vidro ou pano, para que se controlasse o contágio - que agora se acreditava se dar pelo contato entre os pacientes.

A preocupação em torno da assepsia das enfermarias impunha a construção de uma copa e de um aposento na entrada de cada uma delas, para que fossem esterilizados os pratos e quaisquer outros objetos usados ou tocados pelos pacientes. A assepsia estendeu-se aos cuidados com a limpeza e o manuseio dos aparelhos sanitários. Cardoso chegava a sugerir lavatórios e válvulas acionadas pelos pés, cotovelos ou joelhos; o uso de tolhas de papel descartáveis (sem dupla serventia, segundo Cardoso); de sabão individual e capa especial para cada doente, antecipando em décadas as práticas hospitalares usadas e aprimoradas hoje em dia e sobretudo desenvolvidas nos Estados Unidos na década de 1950.

A partir de 1900 houve, nos Estados Unidos, a ampliação da concepção social do hospital, que passou a desempenhar papel relevante na educação, cultura e propaganda contra as moléstias. Entre os anos de 1900 e 1926, segundo Cardoso, foram construídos nos Estados Unidos cerca de 6.700 hospitais, ultrapassando em muito o número de unidades européias. Esses hospitais, para o autor, eram de difícil classificação, pela enorme variedade de plantas e pelo número de andares.

A única indicação do surgimento de uma tipologia nos Estados Unidos é a do bloco vertical. Foi nesse país que surgiram os hospitais em blocos acima de cinco pavimentos. Enquanto na Europa os pavilhões hospitalares não podiam passar de dois pavimentos, nos Estados Unidos os prédios atingiam a impressionante altura de 20 andares, verdadeiros arranha-céus.

Outro fator importante citado por Cardoso era o papel cada vez mais acentuado do arquiteto no desenvolvimento dos projetos 
hospitalares. Novamente a constatação antecipava em décadas a responsabilidade que o arquiteto iria tomar para si na construção dos hospitais, principalmente a partir da arquitetura moderna, que utilizava o programa hospitalar como forma de exercitar o máximo de capacidade de articulação de usos complexos e de conhecimento científico em uma construção civil. ${ }^{20}$ Segundo Rino Levi, que se tornaria um dos maiores representantes da moderna construção hospitalar no Brasil21, a elaboração de um projeto hospitalar depende de uma equipe multidisciplinar composta por médicos e especialistas de diversas áreas, sendo o arquiteto o coordenador, por ser o único capaz de superar os limites da visão particularizada de cada um dos profissionais envolvidos (Anelli, 2001, p. 184).

Depois dessas considerações iniciais, constatamos que o projeto do Hospital Gaffrée e Guinle se insere a meio caminho entre a estrutura pavilhonar que dominou a arquitetura hospitalar ao longo do século XIX - cuja principal característica era a preocupação com o contágio, percebido na separação dos serviços e na aeração dos pavilhões - e a arquitetura em monobloco, que começou a predominar a partir do entreguerras. Como característica desse projeto pode-se mencionar a utilização conjunta das duas tipologias: a pavilhonar, nos edifícios de um a dois pavimentos espalhados pelo terreno, como biotério, capela, casa do diretor, garagem e oficinas; e a do monobloco vertical, localizado no edifício situado no centro do terreno, com quatro pavimentos (sendo um para solário), onde ficavam enfermarias, escritórios, áreas de apoio e a parte correspondente aos serviços hospitalares propriamente ditos. Este bloco apresentava separação em alas - feminina e masculina cada qual com dois elevadores e enfermarias próprias.

A estética arquitetônica acompanhava a separação das duas tipologias: a linguagem estética do neocolonial predominante no Brasil da época dominava o corpo da fachada principal (rua Mariz e Barros) e os prédios menores, principalmente o da capela. Já o bloco de quatro pavimentos apresentava uma estética mais próxima de um classicismo alemão ou austríaco, como de fato observou Licínio Cardoso (op. cit., pp. 196-7).

O próprio d'Ave (op. cit., p. 8) justificava assim o uso do neocolonial: “... sua arquitetura obedece as linhas fortes, sóbrias e perfeitamente definidas do estilo colonial, cuja origem foi trazida através dos tempos, pela tradição dos velhos e grandiosos monumentos erigidos pelos primeiros artistas que aportaram as plagas brasileiras"22. Seria possível afirmar que o projeto do Hospital Gaffrée e Guinle já estaria inserido na construção hospitalar moderna, com forte influência norte-americana?

Vicente Licínio Cardoso chamava a atenção para as diferenças básicas entre a arquitetura americana e a européia. A teoria defendida por este autor é de que as principais inovações incorporadas aos hospitais surgiram na Europa - iluminação, aquecimento, água, gás, esgoto, aeração etc. - foram importadas pelos norte-americanos e acabaram sendo adaptadas e transformadas. Para Cardoso (op. cit., p. 146). 
O hospital europeu traduz o temor do homem em face das teorias rigorosas ditadas pela bacteriologia, enquanto o tipo norte-americano exprime, ao contrário, o destemor hodierno conseqüente as conclusões epidemilógicas e bacteriológicas modernas que abriram horizontes novos, não só a higiene em sua fase profilática, como a medicina na sua ação de assistência hospitalar.

Segundo a concepção norte-americana, um hospital geral moderno precisava ter, além das enfermarias com pequeno número de leitos (de oito a 16), quartos anexos para no máximo duas pessoas (casos especiais) e quartos individuais (se houver pagantes); e anexos às enfermarias suficientemente amplos e bem distribuídos, para o bom funcionamento da enfermagem. As clínicas deveriam ser independentes e subdivididas em: geral, cirurgia, oftalmologia, otorrinolaringologia, obstetrícia e ginecologia, pediátrica (médico-cirúrgica e ortopédica), dermatologia e sifilografia, moléstias infecciosas. Poderia haver ainda clínica de urologia, neurologia e psiquiátrica, cancerosa etc., dependendo das instalações do hospital. A seção de admissão dos doentes (triagem e diagnóstico) deveria ser bem atuante, e se o hospital recebesse muitos doentes deveria ter um dispensário e um ambulatório. Era imprescindível a existência de um instituto de pesquisa para exames bacteriológicos, anátomo-patológicos etc. Também eram fundamentais as instalações de fisioterapia e anexos; serviço de alimentação, lavanderia e casa de máquinas; clínicas pediátricas (que não deveriam receber casos declarados de doenças infecciosas) e a maternidade, que teria tratamento especial, sendo afastada das demais clinicas (idem, ibidem, p. 161).

Por outro lado, um hospital para doenças contagiosas deveria seguir requisitos especiais, que podiam ser resumidos nas palavras do professor (idem, ibidem, p. 163): "As enfermarias não devem ter mais de 12 leitos, devendo ficar metade do número de doentes em quartos de um e dois leitos. Os pavilhões serão de dois ou três andares. Havendo elevador (acima de três pavimentos) — uso para visitantes deve ser diferente do empregado para doentes e pessoal do hospital."

Ao analisarmos a planta do Hospital Gaffrée e Guinle pode-se perceber como esses preceitos foram seguidos pelo arquiteto responsável (Figuras 13, 14 e 15). Porto d'Ave projetou enfermarias nos três andares, com 18 leitos distribuídos em uma única sala, que ele chamava de dormitório, precedidos de dois quartos de isolamento com dois leitos cada um, perfazendo um total de 22 leitos por enfermaria (Figura 16).

Porto d'Ave descreveu seu projeto, nos números 1 e 7-8 da revista A Bandeira, editada pelo Clube dos Bandeirantes entre 1927 e 1929, como "moderno" e com forte influência da arquitetura norte-americana, percebida na sua característica principal: ser um "hospital urbano", onde a questão do afastamento dos centros urbanos era superada para o arquiteto esses são "preconceitos superados". Essa 'urbanidade' só podia ser considerada, como frisamos anteriormente, a partir da compreensão das novas teorias de transmissibilidade, em que a questão 
do contágio e da infecção nos hospitais estava diretamente relacionada à assepsia, à higiene e ao bom funcionamento da enfermagem.

Outros pontos característicos de um hospital "moderno", na concepção de Porto d'Ave (op. cit, p. 8), eram sua função eminentemente socioeducativa, o fato de estar localizado em um ponto de fácil acesso e de ser alegre e atraente. Certamente o Hospital Gaffrée e Guinle está inserido nessa teoria moderna: a feição socioeducativa, como Vicente Licínio Cardoso ressaltou, estava centrada no Instituto de Pesquisa; o fácil acesso foi melhorado ainda mais pela abertura da avenida dos Trapicheiros; e o ambiente "alegre e atraente" podia ser percebido na concepção de um pátio interno com arcadas e arborização. Outras características do hospital reforçam sua 'modernidade', como a separação em alas - feminina e masculina - e a existência de elevadores, dois para cada ala. ${ }^{23}$ Enfim, para o arquiteto, o Hospital Gaffrée e Guinle observava essa doutrina arquitetônica e bacteriológica.

Pesquisando na biblioteca pessoal de Porto d'Ave, guardada por seu neto, Rodolfo, encontramos uma série de recortes da revista Academy Architecture \& Architectural Review do ano de 1926, editada em Londres, com exemplos de hospitais construídos na Inglaterra, mostrando que Porto d'Ave talvez não tivesse contado tanto assim com a arquitetura hospitalar norte-americana. Chamou particular atenção o projeto do The Middlesex Hospital, do escritório Messrs, Young \& Hall (Figura 17). Qualquer semelhança com os projetos de d'Ave não teria sido mera coincidência. A solução da entrada principal em 'U', bem como das enfermarias do Hospital de Middlesex certamente serviu-lhe como fonte de inspiração. A semelhança fica nítida ao analisarmos a entrada principal do Gaffrée e Guinle, o desenho para o Hospital do Câncer da Fundação Oswaldo Cruz e a maquete do terceiro e último projeto de d'Ave para o Hospital das Clínicas. ${ }^{24}$

Talvez João Marinho também tenha percebido isso. O livro de Marinho (op. cit., p. 207) revela que o reconhecimento ao trabalho de d'Ave não era unânime. Ele fazia duras críticas aos projetos de d'Ave para o Hospital das Clínicas, e um dos pontos de ataque era justamente o fato de o engenheiro-arquiteto favorito dos Guinle não ter se baseado tanto nos modelos norte-americanos como deveria. ${ }^{25} \mathrm{~A}$ celeuma obrigou d'Ave a realizar três projetos que continuaram não agradando ao catedrático da Escola de Medicina. Era visível o esforço de d'Ave em apresentar uma solução mais próxima da tipologia norte-americana, no que concerne à altura dos blocos, sem entretanto abandonar os pavilhões, como pode ser visto na maquete (Figura 18). Mesmo assim Marinho (idem, ibidem, p. 207) classificava o último projeto, finalmente aprovado pelo presidente da Assistência, como "... uma monstruosidade de cimento armado sem nenhuma vida a palpitar lá dentro."

Porto d'Ave acreditava que seu projeto era tipicamente norteamericano e, para defender seu ponto de vista e também para responder a João Marinho, publicou na revista $A$ Bandeira um artigo intitulado ' $\mathrm{O}$ 
hospital moderno'. Nele, baseava seu argumento na comparação entre três hospitais: o Centro Médico de Nova York, o Hospital Virchow em Berlim e seu projeto para o Hospital das Clínicas da Faculdade de Medicina do Rio de Janeiro.

Ao falar da arquitetura em bloco, típica da experiência norteamericana, Porto d'Ave chamava a atenção para o fato de que a opção pelo bloco não estava somente ligada à questão da enfermaria, considerada por ele como a cellula matter do 'hospital moderno', mas também ao pouco espaço disponível, sobretudo em Nova York, e ao alto custo das construções, que, na sua opinião, facilitariam a opção pelo 'hospital arranha-céu'.

O arquiteto afirmava que seu projeto para o Hospital das Clínicas era idêntico ao do Centro Médico de Nova York, considerado por ele o maior projeto de organização hospitalar em andamento nos Estados Unidos e descrito como “.... um conjunto de edifícios colados uns aos outros ou ligados entre si por bridges, constituindo grandes monoblocos, considerados unidades, sob um controle único, geral, ao qual ficam subordinados administrativamente" (Porto d'Ave, 1927, pp. 25-6). O contraponto era dado pelo Hospital Virchow, de Berlim, formado por um conjunto de 38 pavilhões, sendo 21 de especialidades médicas, somente com um andar.

Para dar maior ênfase a sua teoria, apresentava um quadro comparativo da área disponível versus o número de leitos versus a área/número de leitos de cada hospital, de certa forma apontando para as vantagens de seu projeto, tanto sobre o nova-iorquino quanto sobre o alemão:

\begin{tabular}{llll}
\hline & área disponível & número de leitos & área/número de leitos \\
\hline Centro Médico de NY & $80 \mathrm{mil} \mathrm{m2}$ & $2 \mathrm{mil}$ & $40 \mathrm{~m} 2$ por enfermo \\
Hospital das Clínicas RJ & $144 \mathrm{mil} \mathrm{m2}$ & 1800 & $80 \mathrm{~m} 2$ por enfermo \\
Hospital Virchow, Berlim & $240 \mathrm{mil} \mathrm{m2}$ & $2 \mathrm{mil}$ & $120 \mathrm{~m} 2$ por enfermo \\
\hline
\end{tabular}

Por fim, afirmava que "O sistema de monoblocos adotado na organização do Hospital das Clínicas da Faculdade de Medicina do Rio de Janeiro, idêntico ao Centro médico de Nova York, oferece sobre o ponto de vista orçamentário a possibilidade de ser executado por partes, de acordo com a arrecadação do imposto votado para este fim" (idem, ibidem, p. 30). D'Ave publicava ainda os pareceres do dr. Burlingame, idealizador do Centro Médico nova-iorquino, que considerava o projeto do Hospital das Clínicas um "excelente trabalho"; e do dr. Manoel Quintella, reitor e decano da Universidade de Montevidéu, que chegava a solicitar-lhe detalhes do projeto para serem incluídos na planta do Centro Médico que o governo do Uruguai pretendia construir.

Em nossa opinião, foi somente com o Hospital dos Servidores que Porto d'Ave conseguiu adotar plenamente a tipologia norte-americana, projetando, ali sim, um monobloco de dez pavimentos bastante 


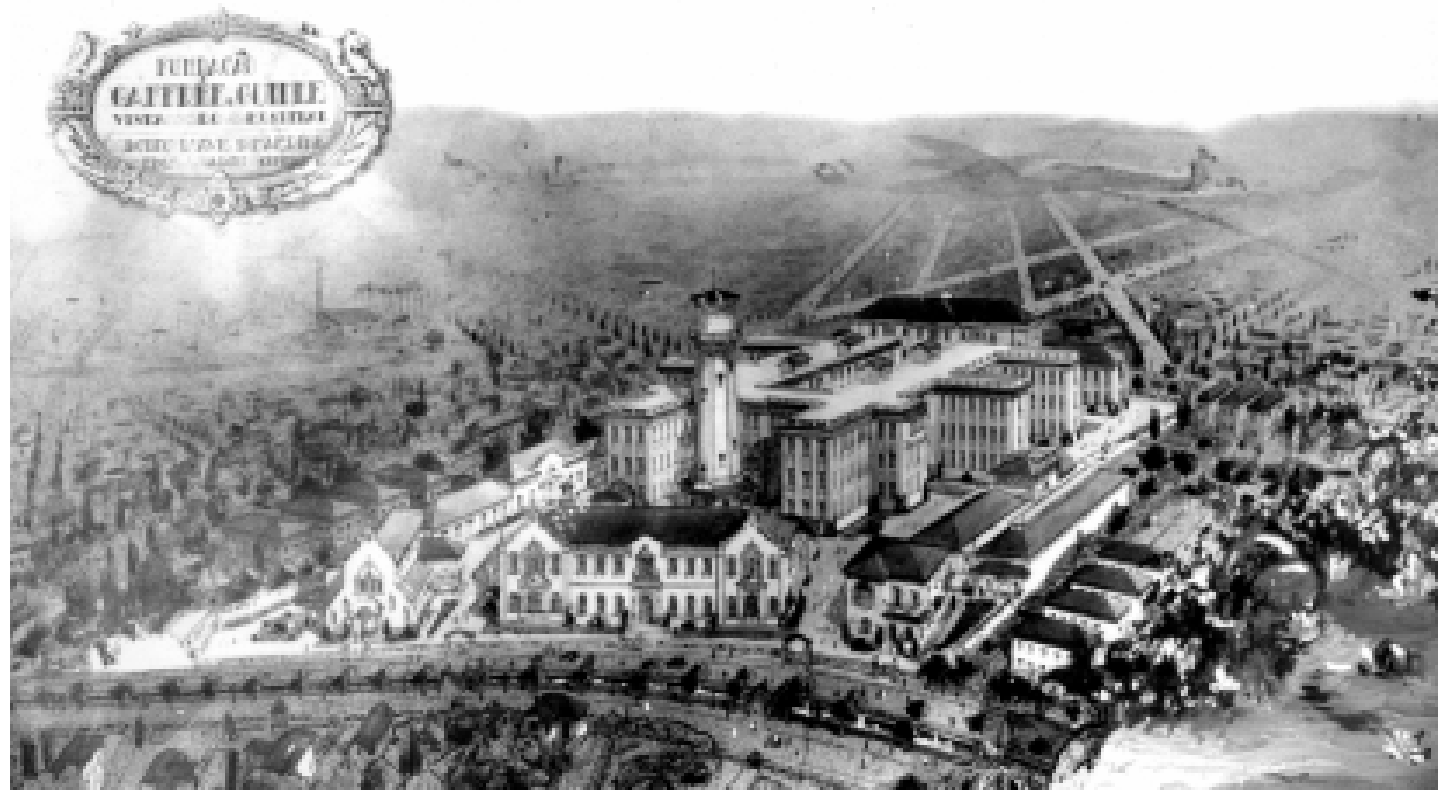

Figura 1 - entre nós Vista aérea do Hospital Gaffrée e Guinle, na rua Mariz e Barros, projeto Porto d'Ave \& Haering, Eng ${ }^{\mathrm{s}}$ e $\mathrm{Arch}^{\circ}$

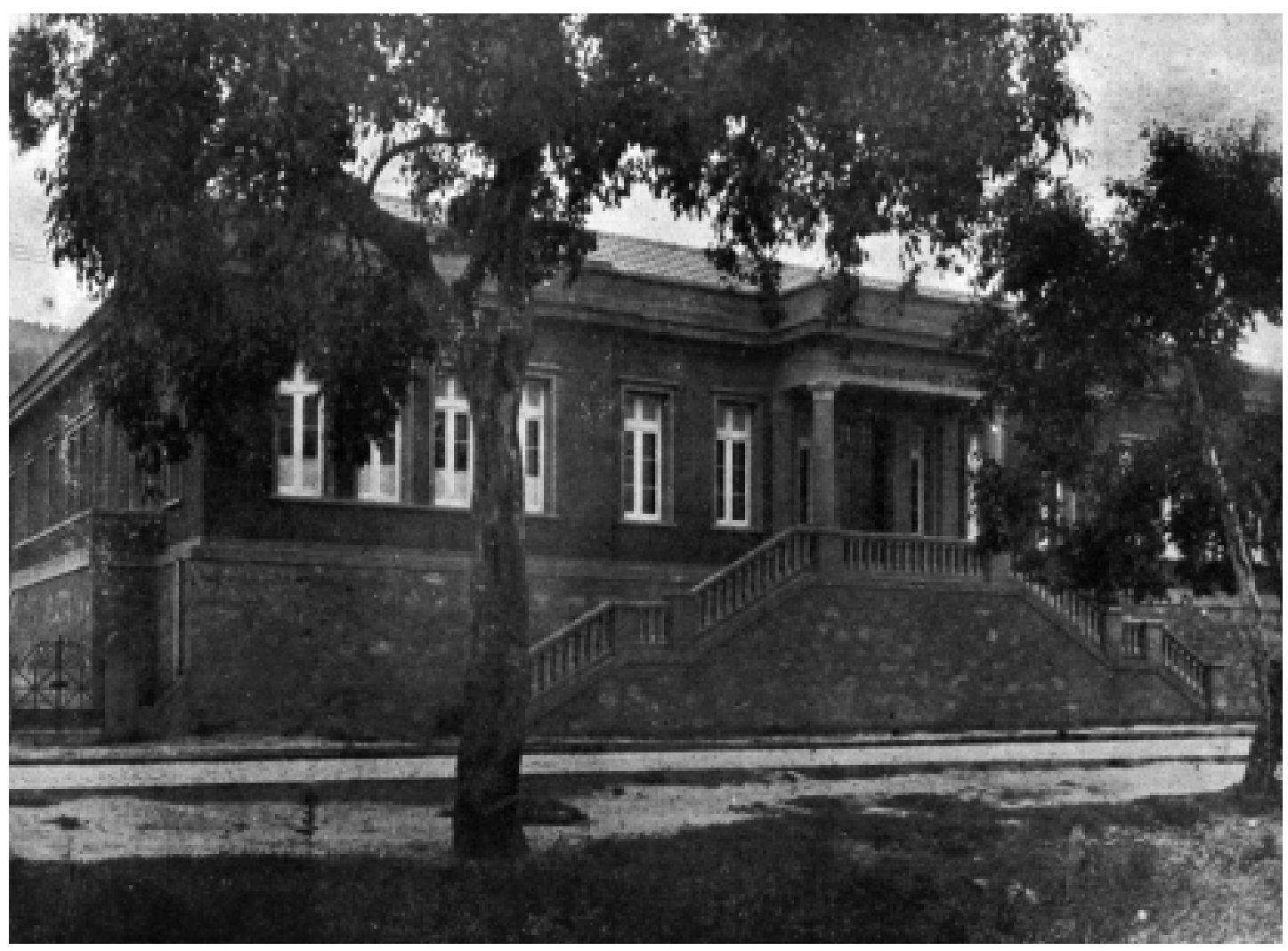

Figura 2 - Fundação Gaffrée e Guinle, ambulatório n. 3 - rua Maria Flora, n. 17, Engenho de Dentro 


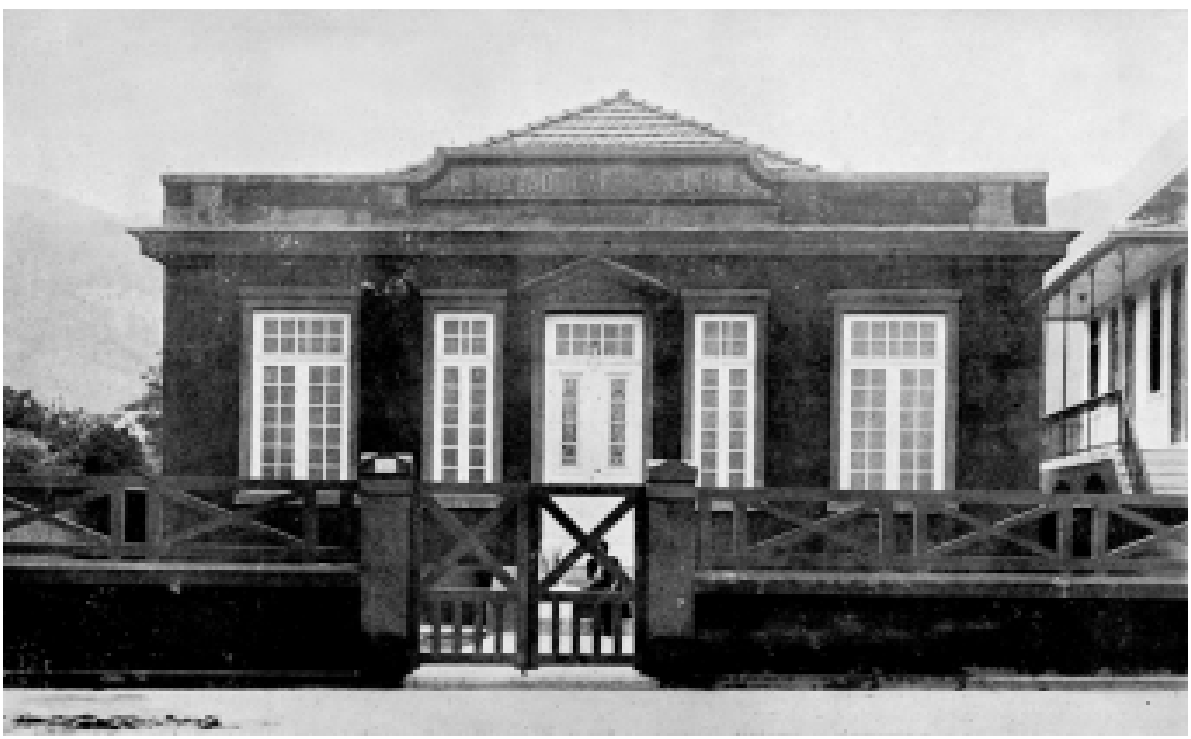

Figura 3 -

Fundação

Gaffrée e Guinle,

ambulatório

n. 5 - rua Barão

de Mesquita, $n$.

955, Andaraí.

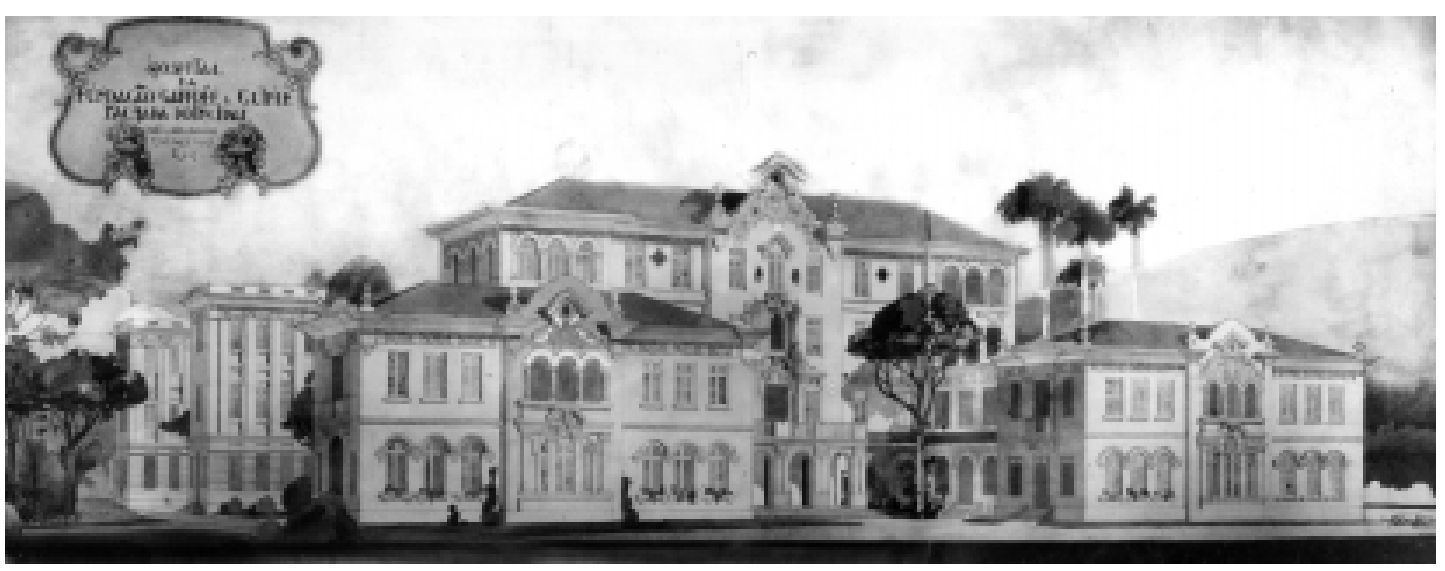

Figura 4 - Hospital da Fundação Gaffrée e Guinle, fachada principal, projeto Porto d’Ave \& Haering, Eng e Arch $^{\text {s }}$

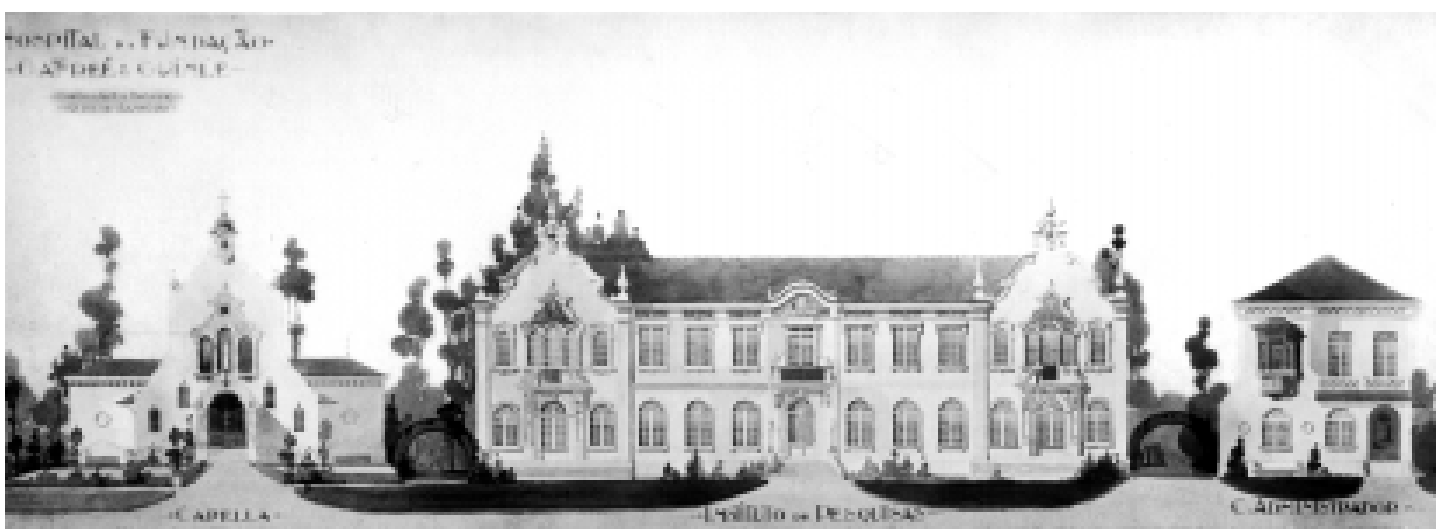

Figura 5 - Hospital da Fundação Gaffrée e Guinle, fachada da rua projetada com a capela, o Instituto de Pesquisa e a casa do administrador, projeto Porto d'Ave \& Haering, Eng ${ }^{5}$ e Arch $^{\text {os }}$ 

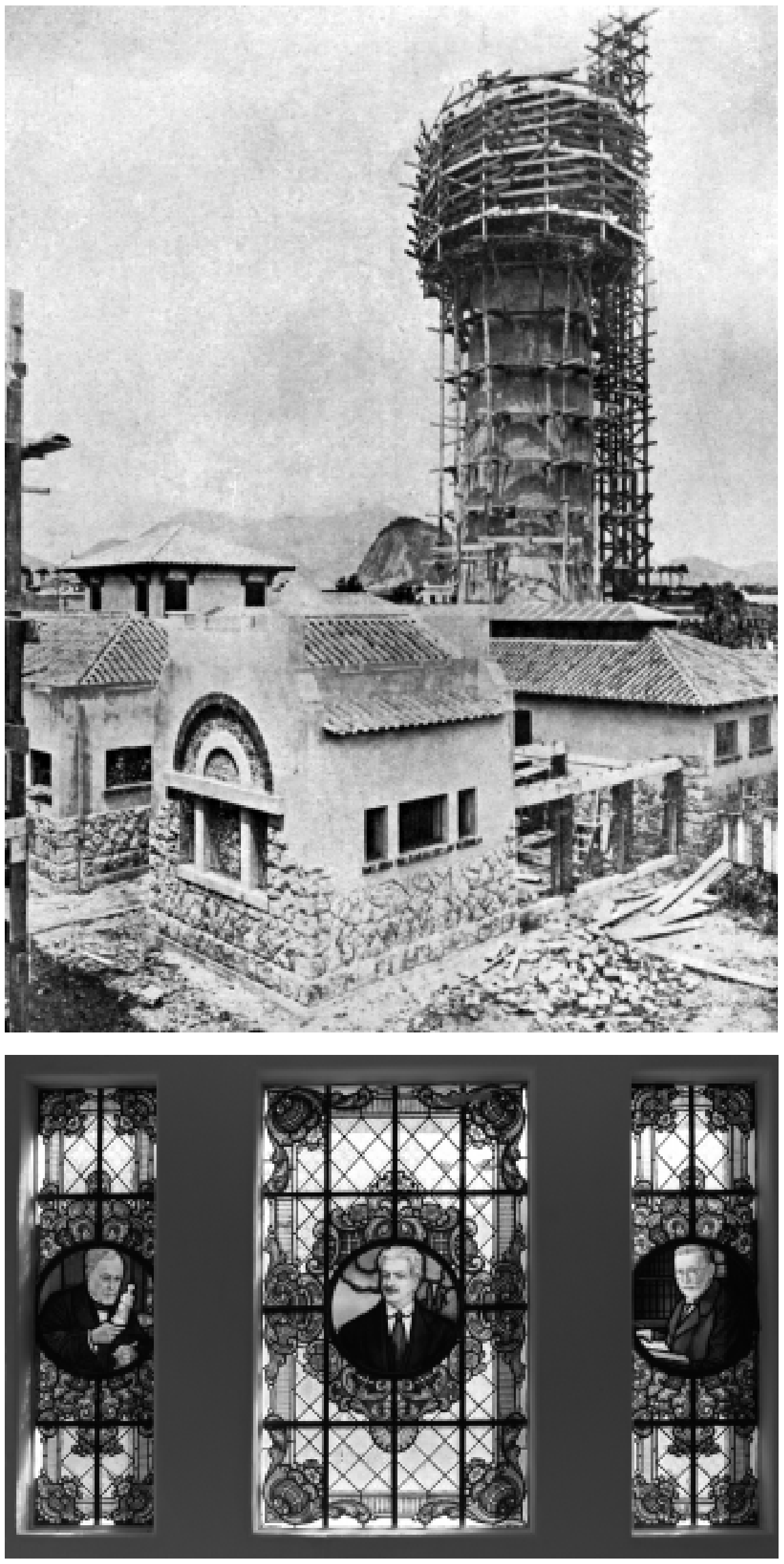

Figura 6 - O

hospital Gaffrée e Guinle durante as obras de construção. Em destaque ao fundo, a torre d’água

Figura 7 - Vitral localizado na escada de acesso ao primeiro pavimento do biotério. Do lado direito, Louis Pasteur; ao centro, Oswaldo Cruz; e a esquerda, Robert Koch.

Foto Roberto Jesus Oscar e Vinícius Pequeno de Souza DAD/COC 


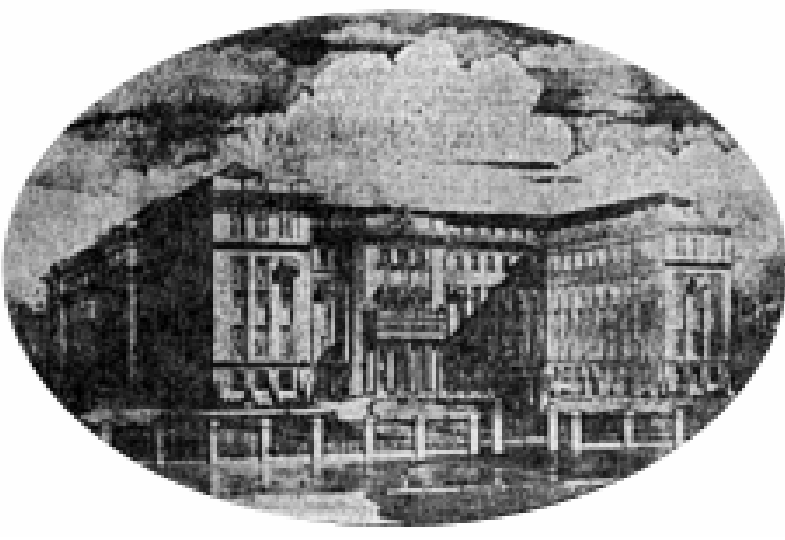

Figura 8 - Hospital do Câncer da Fundação Oswaldo Cruz. Perspectiva e fachada principal

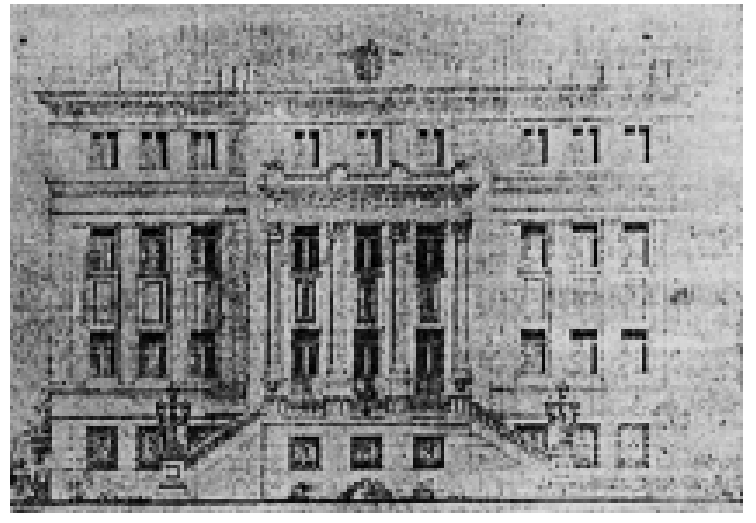

Figura 9 - Instituto de Pesquisa do Hospital do Câncer da Fundação Oswaldo Cruz. Fachada principal

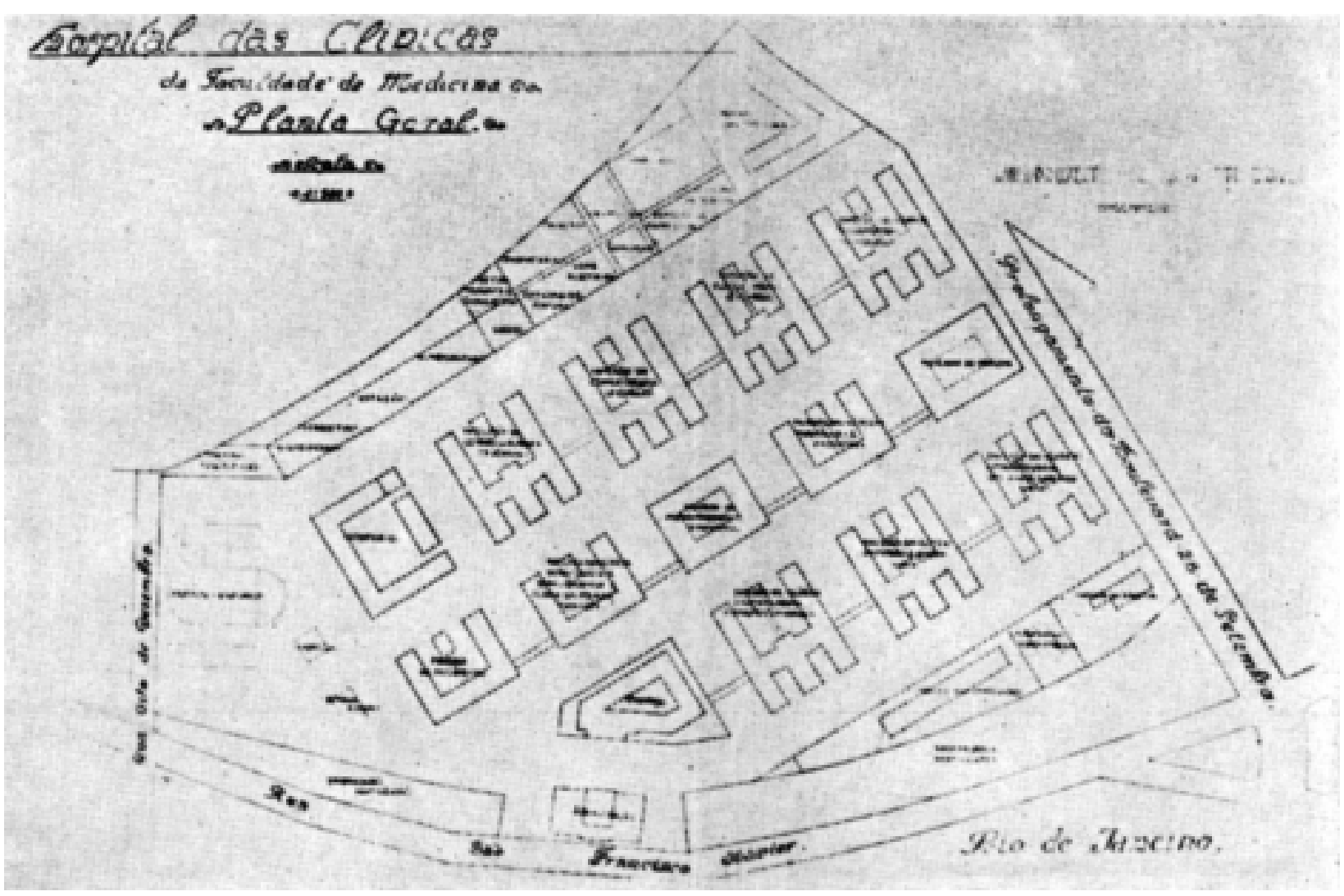

Figura 10 - Primeira planta do Hospital das Clínicas, arquiteto Porto d’Ave (apud Marinho, 1931) 


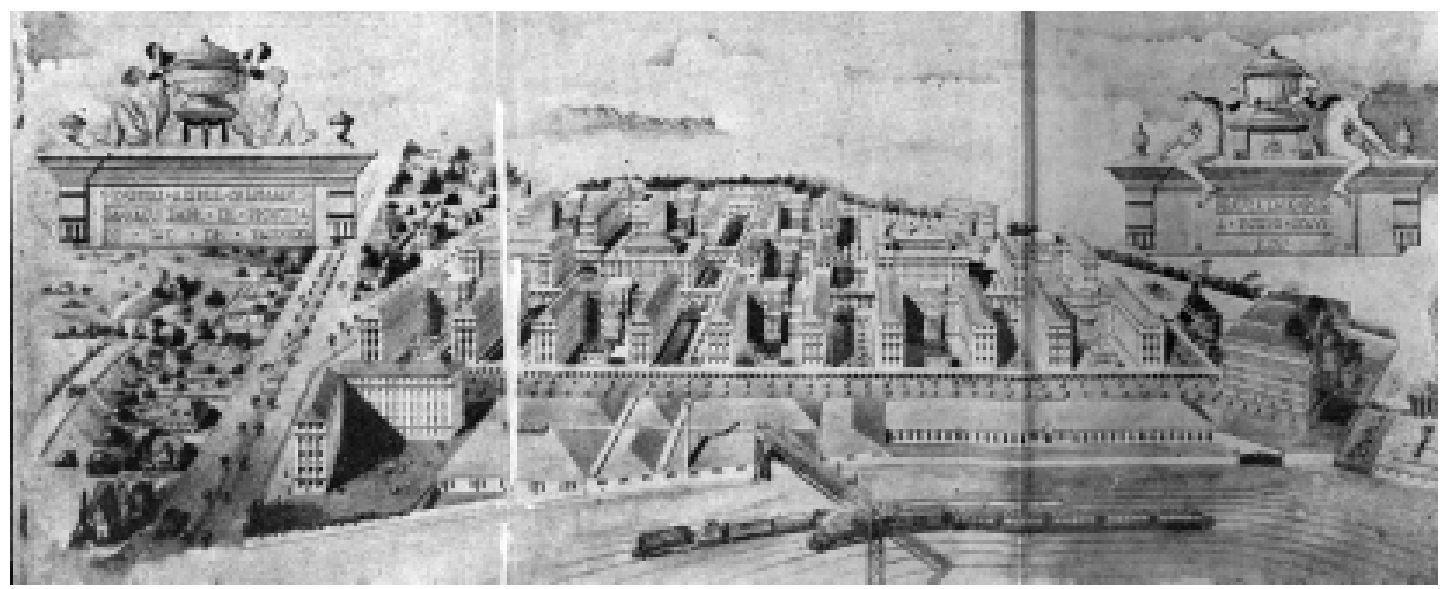

Figura 11 - Terceira e definitiva planta do Hospital das Clínicas, arquiteto Porto d’Ave (apud Marinho, 1931)

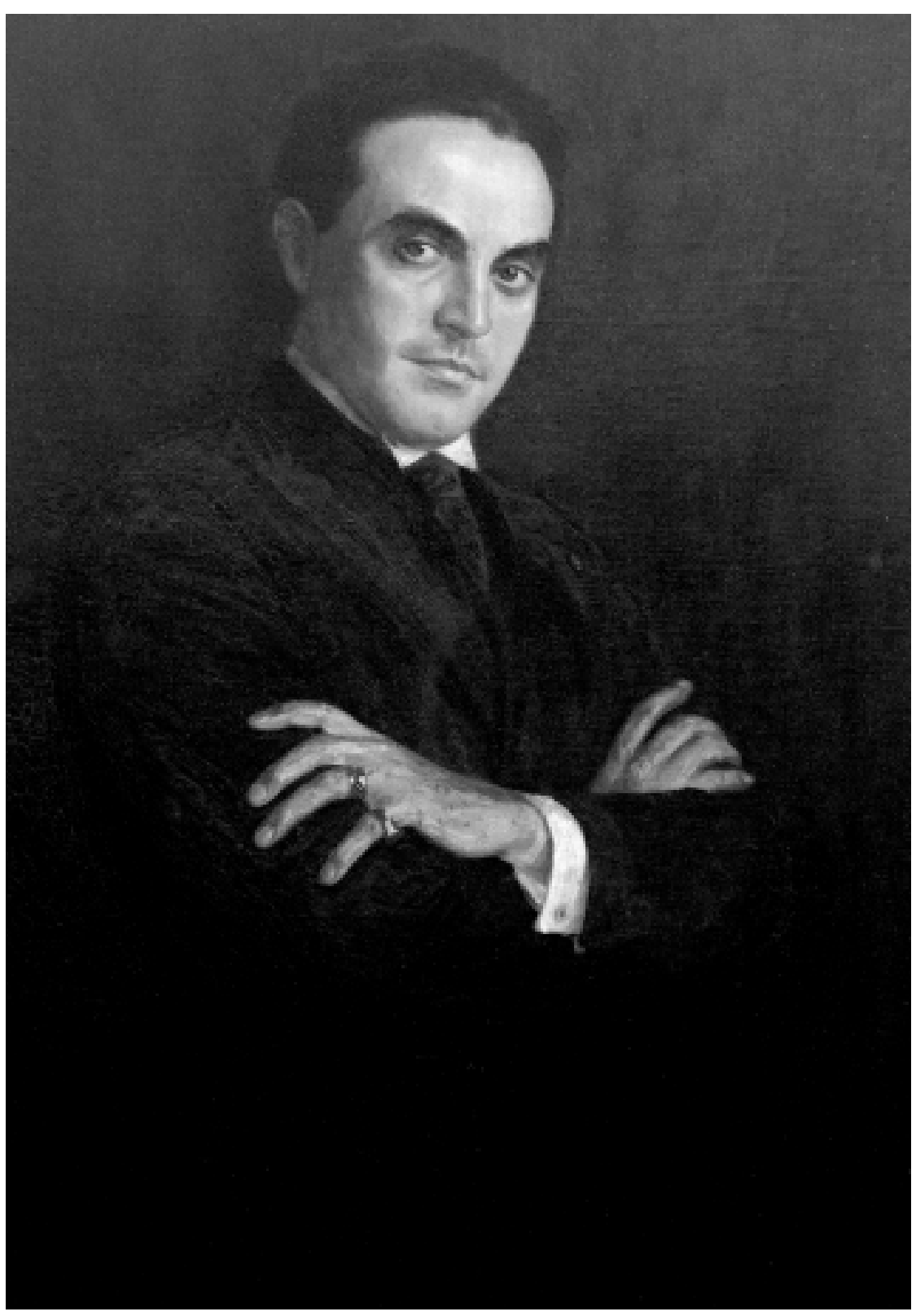

Figura 12 - Retrato de Porto d'Ave.

Foto Roberto Jesus Oscar e Vinícius Pequeno de Souza $\mathrm{DAD} / \mathrm{COC}$ 

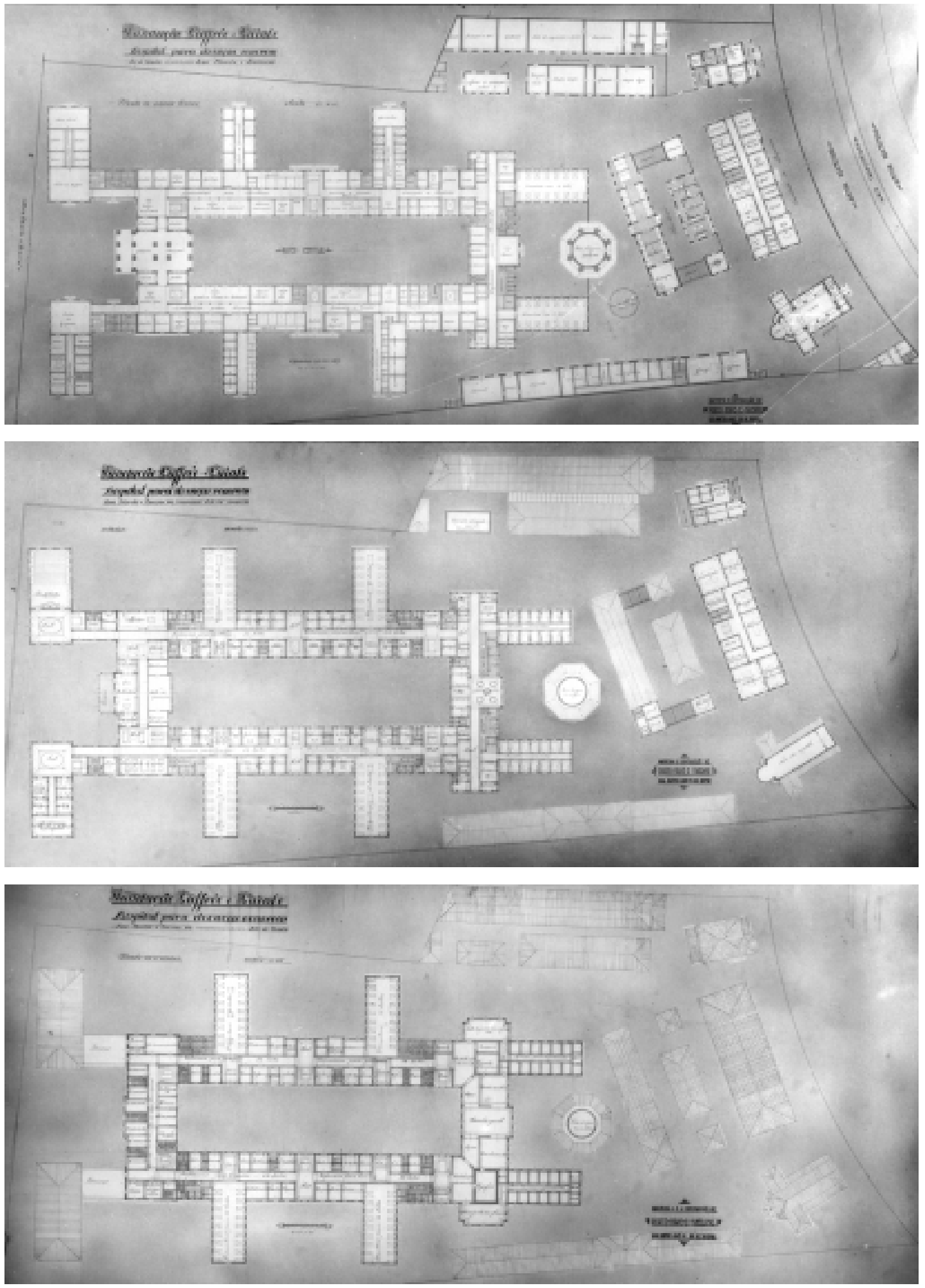

Figura 13, 14, e 15 - Plantas do térreo, primeiro e segundo pavimentos Hospital Gaffrée e Guinle 


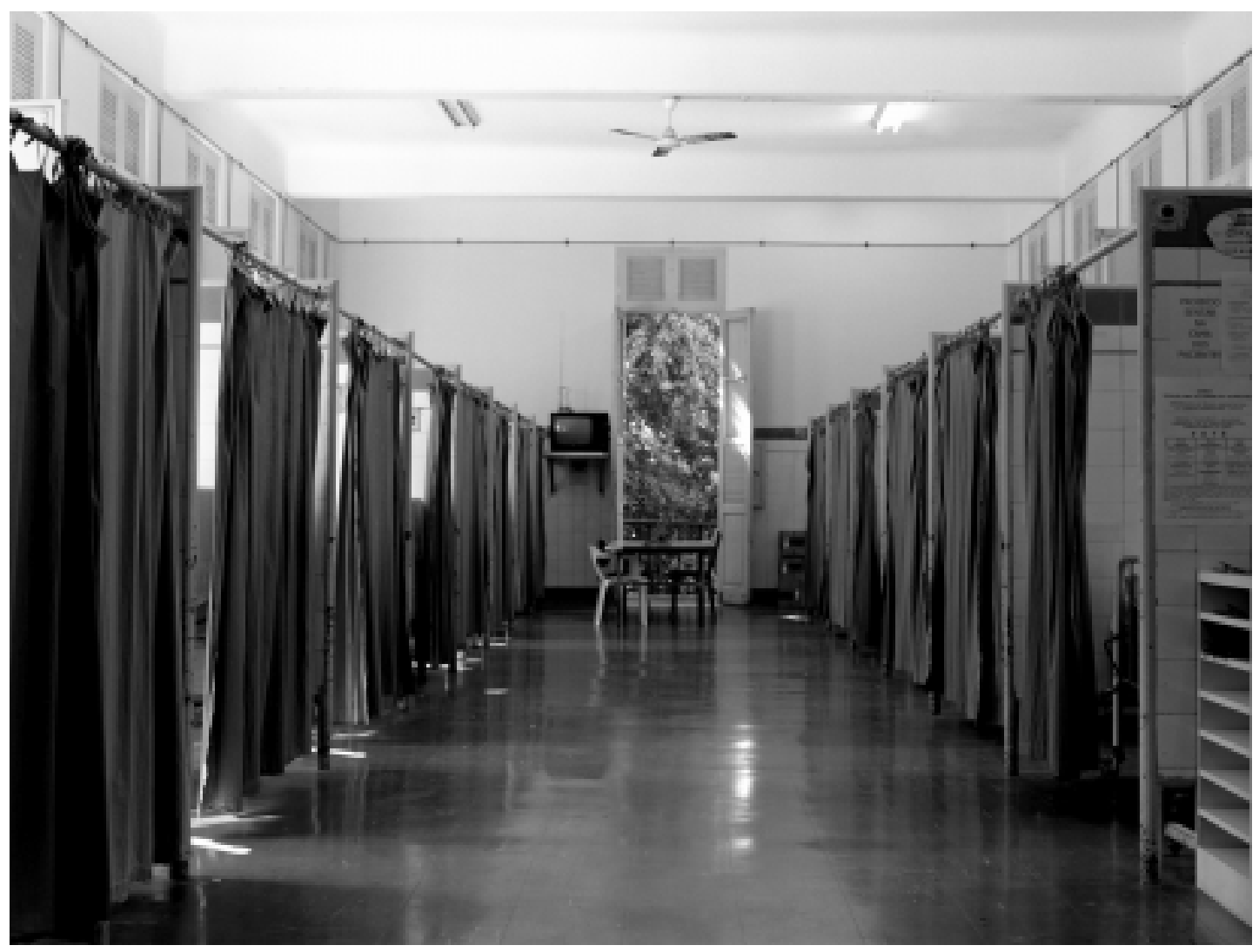

Figura 16 - Enfermaria n. 3. Foto Roberto Jesus Oscar e Vinícius Pequeno de Souza DAD/COC

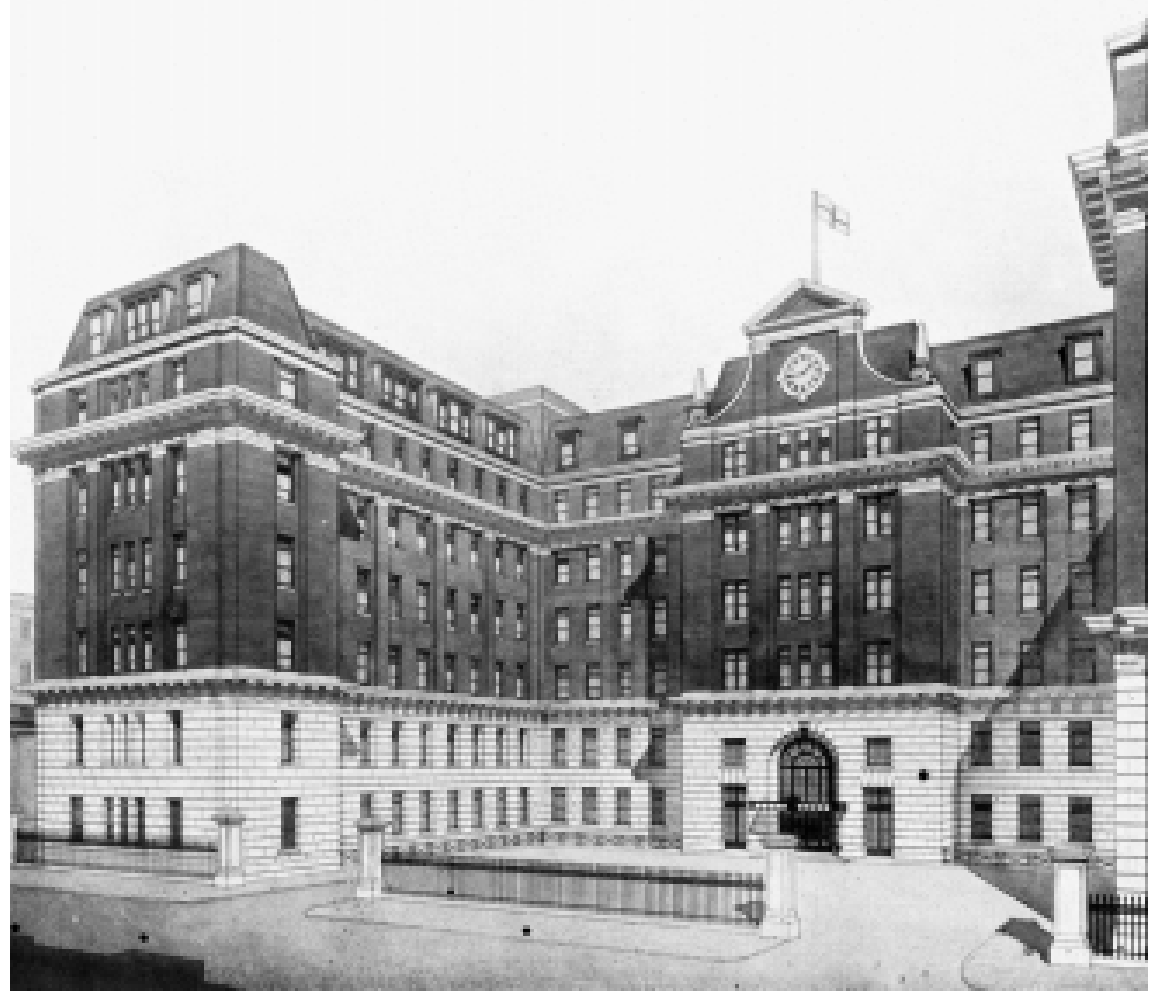

Figura 17 - Fachada

do Hospital de Middlessex, Londres 


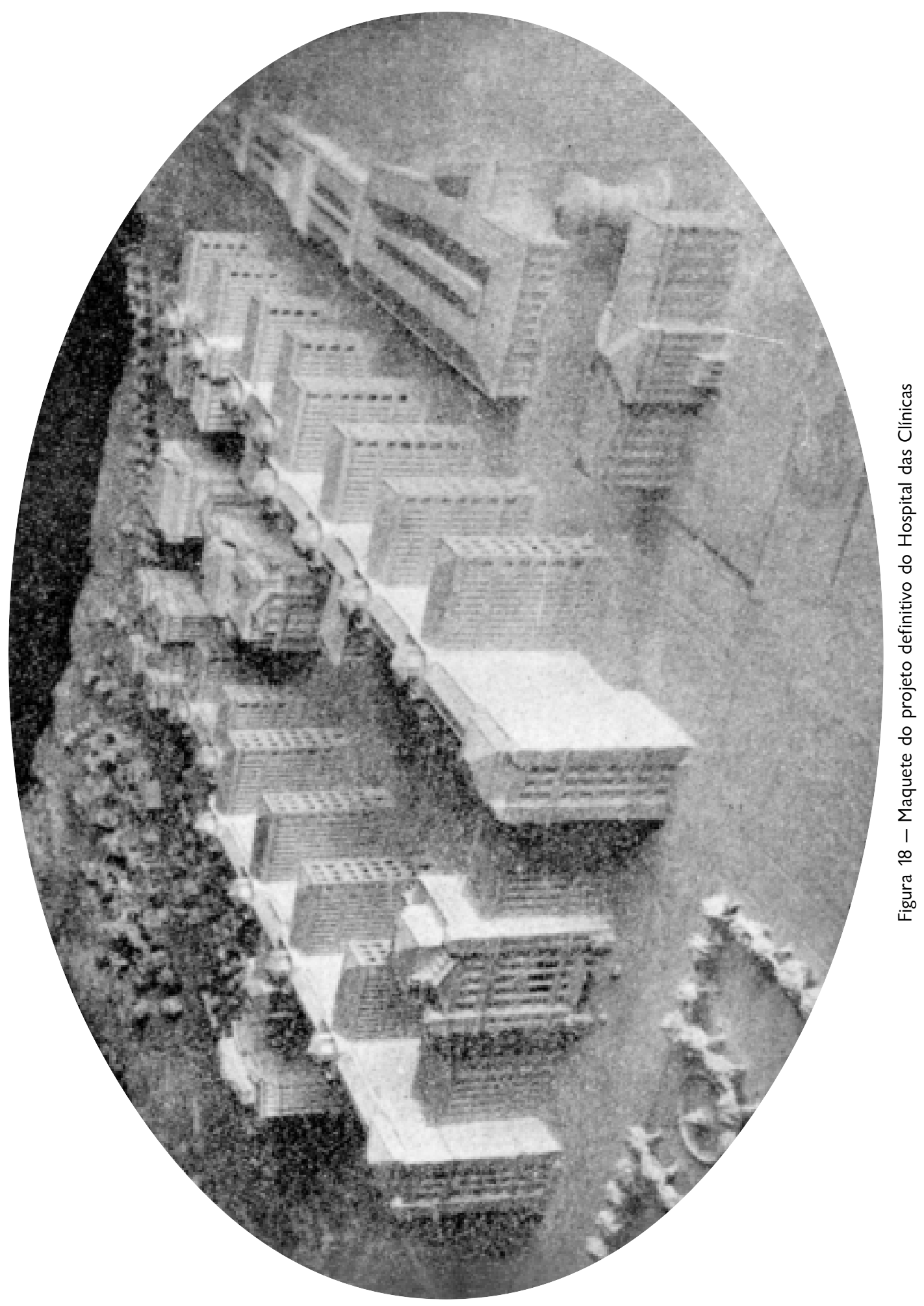


semelhante aos exemplificados por Marinho em seu livro. D'Ave obteve o primeiro lugar no concurso realizado em 1935 e contou com a assessoria do médico Felix Lamela, da Universidade John Hospkins e da União Panamericana (Morínigo, 2001).

\section{Conclusão}

A década de 1920 foi marcada por grandes mudanças na saúde pública, atingindo em maior ou menor grau a construção de hospitais na cidade do Rio de Janeiro. Como foi acentuado ao longo deste artigo, a questão da assistência hospitalar na capital estava passando por um momento crítico, no qual a falta de hospitais gerais destinados a atender um público vasto e empobrecido era latente. Deve-se deixar claro que existiam outros hospitais na cidade, porém com atendimento era restrito, estando ligados às diversas associações de auxílio mutuo, aí entendidas tanto as irmandades e ordens terceiras - cujo atendimento era restrito aos 'irmãos' - quanto os hospitais militares (Central do Exército, da Marinha, Policlínica Militar, Corpo de Bombeiros), destinados a seu público específico; e também os ligados às sociedades de benemerência, como o Hospital da Beneficência Portuguesa ou o dos Ingleses; e ainda o Hospital Oswaldo Cruz, construído no campus do Instituto Oswaldo Cruz e destinado a atender às doenças tropicais (malária e febre amarela) ou às endemias estudadas pelos pesquisadores da instituição. O grosso da população não tinha acesso a esses hospitais.

As pequenas mudanças percebidas no período, com a ampliação da capacidade de atendimento das duas policlínicas e a criação do Hospital São Francisco de Assis, em 1922, não foram suficientes para reverter o quadro.

Por outro lado, os três hospitais aqui analisados podem ser entendidos, primeiro, como uma resposta por parte da classe médica ao controle de determinadas doenças - a sífilis e o câncer - até então desconsideradas pelo poder público, apesar de estarem bem colocadas no ranking de causa mortis na cidade e de todo o simbolismo que envolvia a sífilis a degeneração da raça. Em segundo lugar, a questão do déficit de hospitais gerais deveria ser resolvida com a construção do Hospital das Clínicas, aquele que viria a ser, se concluído, o maior da cidade. Em todo caso, dos três projetos hospitalares desenvolvidos ao longo da década de 1920, somente um deles conseguiu lograr êxito, Gaffrée e Guinle. Os hospitais do Câncer e das Clínicas tornaram-se um retumbante fracasso, embora o prédio do primeiro tenha sido utilizado posteriormente para fins hospitalares. A questão da assistência hospitalar ficou para ser resolvida a posteriori.

Em termos de arquitetura, o estudo dos trabalhos do arquiteto Porto d'Ave nos permite observar que a influência da arquitetura norteamericana - o monobloco - se fez sentir antes do que habitualmente é considerado como o período moderno da arquitetura hospitalar, a 
partir de meados da década de 1930. A época foi fortemente caracterizada pela passagem de um tipo de arquitetura a outro - do pavilhão ao monobloco —, e os projetos de Porto d'Ave são a prova desse processo que teve longa duração. O estudo desses trabalhos também nos permite refletir sobre o papel, nem sempre notado, do arquiteto no desenvolvimento de projetos hospitalares.

Todas as dificuldades mencionadas no andamento das obras dos hospitais do Câncer e das Clínicas também são paradigmáticas daquele momento de transição, em que cada ator - fosse ele médico ou arquiteto - desejava delimitar seu espaço, ao mesmo tempo que as novas teorias transformavam os conhecimentos existentes. Aquela foi uma época de grandes transformações na prática médica, na arquitetura e na engenharia, mudanças que só se tornariam mais visíveis na década seguinte.

\section{NOTAS}

${ }^{1}$ Nossos agradecimentos à família Guinle de Paula Machado, que gentilmente permitiu-nos o acesso a seu acervo, bem como nos cedeu as imagens do Hospital Gaffrée e Guinle; a Rodolfo Porto d'Ave, que nos forneceu informações preciosas sobre seu avô, cedendo-nos imagens e documentos; a Fernando Vasconcellos, que tratou as imagens do Hospital Gaffrée e Guinle; a Roberto Jesus Oscar e a Vinícius Pequeno de Souza, pelo tratamento das imagens do Hospital das Clínicas e pelas fotografias do Hospital Gaffrée e Guinle e da família Porto d'Ave; e à direção do Hospital Gaffrée e Guinle, na figura dos doutores Pedro Portari Jr. e Agostinho Ascenção, por nos terem franqueado as instalações para nossas investigações.

${ }^{2}$ Podemos citar Manguinhos do sonho a vida, publicado pela Casa de Oswaldo Cruz em 1990, em que os autores analisam a arquitetura hospitalar nas primeiras três décadas do século XX por meio da obra do engenheiro-arquiteto português Luiz Moraes Jr., livro paradigmático para essas questões e que influenciou uma geração de pesquisadores, entre historiadores e arquitetos, sobre o tema da arquitetura hospitalar. (Ver nota 4). Citamos também o trabalho de Tânia Bittencourt, Arquitetura sanatorial de São José dos Campos, publicado em 1998, e sua dissertação de mestrado Peste branca, arquitetura branca, defendida em 2000, na USP/São Carlos, sob orientação de Hugo Segawa, em que a autora analisa os sanatórios de tuberculosos no Brasil na primeira metade do século XX, com destaque para o sanatório de Curicica, no Rio de Janeiro. Sobre o mesmo sanatório foi publicado em 2003, no site www.vitruvius.com.br, o artigo de número 26.02, 'O Sanatório de Curicica, uma obra pouco conhecida de Sérgio Bernardes, de Nascimento, D. et alii.

${ }^{3}$ Vale ressaltar que a Fundação Oswaldo Cruz, objeto de analise deste artigo, criada em 1922 e extinta em 1936, não tem relação com o Instituto Oswaldo Cruz, criado em 1900, nem com a atual Fiocruz. Como mostraremos mais adiante, seu objetivo maior era honrar a memória do médico Oswaldo Cruz, então recentemente falecido.

${ }^{4}$ Um outro importante profissional a surgir nas primeiras três décadas do século XX foi o português Luiz Moraes Jr., que trabalharia, primeiramente a convite de Oswaldo Cruz e depois por Carlos Chagas e Pedro Ernesto, em projetos e construção de hospitais no Rio de Janeiro. Moraes foi o responsável por: projeto e construção da Policlínica da Avenida Central (1904); Desinfectório de Botafogo (atual Hospital Rocha Maia, 1905); reformas do Hospital do Engenho de Dentro (1908); projetos de novos pavilhões, reforma e construção dos hospitais de São Sebastião (1908) e de Jurujuba (1909); projeto e construção do Hospital Oswaldo Cruz (1912-1918), em Manguinhos; reformas dos pavilhões da Beneficência Portuguesa (1923); e finalmente projetos de unidades hospitalares construídas em parte ou integralmente na gestão do prefeito Pedro Ernesto (1933-1936). Tudo isso sem falar da participação de Moraes no projeto de um dispensário da própria Fundação Gaffrée e Guinle (Benchimol, 1990, pp. 226-7).

${ }^{5}$ Mesma observação feita por Benchimol (op. cit., p. 189) em relação aos hospitais projetados por Moraes. Na nossa opinião, Porto d'Ave foi além de Moraes nessa fase de transição, pois chegou a projetar e construir monoblocos verticais verdadeiramente inspirados na tipologia norte-americana.

${ }^{6}$ Vicente Licínio Cardoso ficou mais conhecido por ser um dos principais ideólogos da construção nacional a partir do trabalho À margem da história do Brasil, editado postumamente em 1933, e por sua militância em prol da educação básica. Sua formação inicial, contudo, era de engenheiro, graduado pela Escola Politécnica, da qual foi professor (Santos, s. d.); dedicou parte de sua vida intelectual ao estudo da arte e da arquitetura.

7 Miquelin, 1992; Risse, 1999; Murken (1994), originalmente publicado como Kommunale Leistungsverswaltung und Stadenwicklung vom Vormärz biz zur Weimarer Republik. Colônia/Viena, Bóhlau, 1990 em Colônia e Viena, transformado em artigo e traduzido por Anthony Sutcliffe em 1994. 
${ }^{8}$ Guilherme Guinle nasceu em 1882 no Rio de Janeiro. Segundo filho de Eduardo Palassin Guinle e Guilhermina Guinle, faleceu na mesma cidade, em 20 de maio de 1960. Seu pai era engenheiro ferroviário e, juntamente com o sócio Cândido Gaffrée tornou-se concessionário da Companhia Docas de Santos no final do século XIX. Por insistência familiar, ingressou na Escola Politécnica, onde se formou engenheiro. Apesar de não ser o primogênito, coube a Guilherme a direção dos negócios da família. Sua trajetória como homem de negócios foi brilhante: assumiu a direção da Companhia Docas de Santos, do Banco Boavista, foi o primeiro presidente da Companhia Siderúrgica Nacional e presidente do Banco do Brasil, entre outros empreendimentos. Era freqüentador dos principais clubes da cidade, entre eles o Jockey Clube e o Clube de Engenharia, do qual se tornou sócio benemérito, como seu padrinho Candido Gaffrée. Em 1941 teve seu nome inscrito no então recémcriado Livro do Mérito, comenda que Getúlio Vargas criou com o intuito de homenagear as pessoas que tivessem feito doações vultosas ou trabalhos relevantes em prol do enriquecimento material ou espiritual da nação, e que Guilherme recebeu por suas inúmeras ações de filantropia e mecenato (Barros, 1982).

${ }^{9}$ Essa correspondência não se encontra entre os documentos da Fundação Oswaldo Cruz depositados no Arquivo da Casa de Oswaldo Cruz.

${ }^{10}$ Na década de 1920, a Liga Brasileira Contra a Tuberculose se transformou em Fundação Liga Brasileira Contra a Tuberculose, sob a clara influência do surgimento das Fundações Oswaldo Cruz e Gaffrée e Guinle (Nascimento, 2002).

${ }^{11}$ Pode parecer estranha a indicação do diretor do hospital logo no início das obras de construção, mas deve-se levar em consideração que já havia ambulatórios em funcionamento que faziam parte do complexo hospitalar mantido pela Fundação Gaffrée e Guinle, e que o diretor do hospital respondia administrativamente por ele. A Gilberto de Moura Costa sucederam José Thompson Mota (1938-44), Joaquim Mota (1944-46) e Henrique de Moura Costa (1946-58).

${ }^{12}$ Segundo depoimento do próprio João Marinho (1931, p. 32), ele levou cerca de dois meses para refletir se aceitaria ou não a incumbência proposta pelo presidente Washington Luiz; neste ínterim, Carlos Chagas teria respondido interinamente pelo órgão.

${ }^{13}$ A celeuma entre Marinho e d'Ave está devidamente documentada na publicação Ocasião perdida. Depoimento prestado perante a Comissão de Sindicância das Obras do Hospital das Clinicas (1931). Nesse pequeno livro Marinho reunia todos os projetos e documentos relacionados ao caso, inclusive opiniões suas bastante tendenciosas, apoiadas em análise histórica acerca da arquitetura hospitalar européia e norte-americana.

${ }^{14}$ Godoy (1876-1944) foi outro de nossos engenheiros expoentes que desenvolviam diversas atividades de engenharia e mesmo de arquitetura e urbanismo, tendo participado, juntamente com Saturnino de Brito, do I Congresso Brasileiro de Higiene, de 1923. Atuava tanto nas questões de saneamento das cidades quanto na elaboração de planos de melhoramentos, abertura de estradas etc. Godoy também foi diretor do Automóvel Clube do Brasil, a partir de 1935.

${ }^{15}$ Em relação a este sócio de d'Ave no escritório da rua Buenos Aires, 52, nada foi encontrado, apenas que seu primeiro nome era Kurt e que era o sócio de número 263 do Clube dos Bandeirantes.

${ }^{16}$ Apesar de ter nascido sete anos antes de o pai ter sido agraciado com este título, na certidão de nascimento de Aldestano Soares de Mattos, existente nos arquivos da antiga Escola Politécnica, consta ser ele filho dos 'condes' de Porto d'Ave. Acreditamos que a certidão tenha sido alterada para inserir o título nobliárquico de seu pai, embora diferente do que consta na Carta de Mercês de 1897. Isso certamente facilitou-lhe o ingresso aos principais clubes e salões da cidade.

${ }^{17}$ Porto d'Ave prestou provas para ingresso na Politécnica nos anos de 1908 e 1909; colou grau em 31 de março de 1919. Dentre as diversas especialidades oferecidas pela Escola Politécnica, optou pela de engenheiro-geógrafo, cuja ênfase era posta no estudo do espaço físico, dando a entender que se podiam incluir questões relativas ao espaço urbano também. Entrou para o curso adotando o sobrenome de Soares de Mattos apenas. Passou a assinar Adesltano Soares de Mattos Porto d'Ave a partir de fevereiro de 1922.

18 As transformações pelas quais o Hôtel de Dieu passou a partir do final do século XVIII são paradigmáticas para compreendermos todo o processo de medicalização do hospital, ao mesmo tempo que se transformavam no novo conceito de hospital: cada um de seus 1.400 leitos abrigaria uma só pessoa; foi definida a separação por sexo e a separação entre doentes e casos cirúrgicos, entre outros (Ackerknecht, 1986, pp. 35-6).

${ }^{19}$ Para maiores informações sobre o tema conferir Ackerknecht (1986), Foucault (1977) e Risse (1999, cap. 6).

${ }^{20}$ Podemos citar a propósito, a cuidadosa escolha dos materiais, em que a madeira deveria ser substituída pelo ferro e pelo concreto, o uso de materiais facilmente 'laváveis' a propósito, como as cerâmicas e os azulejos e sobretudo a ausência de ornamentos nos edifícios hospitalares. Outros temas demandaram a atenção de Vicente Licínio Cardoso, como a escolha correta das instalações sanitárias, a altura adequada dos pavimentos — quatro ou cinco metros —, a iluminação e a ventilação, tanto mecânicas quanto naturais, e a necessidade de os hospitais terem seus próprios reservatórios d'água, com processo de filtragem e correção.

${ }^{21}$ Rino Levi (1901-65) realizou em São Paulo os projetos da Maternidade da Universidade de São Paulo, 1945; do Hospital Central do Câncer, 1947; do Hospital da Cruzada Pró-Infância, 1950; do Hospital Albert Einstein, 1958. Na Venezuela, os do Hospital Central de Caracas, 1959, de Maiquetia, 1959 e de Puerto Cabello, 1960. 


\begin{abstract}
${ }^{22}$ Não é de estranhar que Porto d'Ave tenha se utilizado da estética neocolonial em seus projetos. Esse estilo representava a modernidade em arquitetura na segunda metade da década de 1920 e “... uma reação contra a arquitetura importada da Europa e o anseio por uma forma de decorativismo brasileiro" (Czajkowski, op. cit., p. 16), antes da consolidação do Movimento Moderno, a partir da década seguinte. O que é estranho, mesmo para os estudiosos do estilo, é sua estética mais calcada na tradição hispânica e não propriamente em uma estética brasileira. A explicação que se pode dar é que essa estética estaria buscando uma identificação com a América Latina e eus povos descobridores, e não apenas à metrópole portuguesa. Vale a pena ainda ressaltar que faziam parte do Clube dos Bandeirantes alguns dos maiores defensores do neocolonial, como o médico José Mariano Filho (sócio nº 101) e o engenheiro Heitor de Mello (sócio no 271), e que, como homens bandeirantes, eles deveriam amar a terra e o homem do Brasil.

${ }^{23}$ O hospital conta, na verdade, com seis elevadores: dois em cada uma das alas e mais dois no corredor de ligação entre as duas alas.

${ }^{24}$ A última frase do verbete escrito para o Hospital da Mariz e Barros para o Guia da Prefeitura do Rio de Janeiro (2000), em que se observa que a “... conformação final em U aberto para a rua é comum a outros hospitais da época”, fica agora mais bem compreendida.

${ }^{25}$ João Marinho atacou também a reputação profissional de d'Ave. Afirma Marinho à página 75: "Entre os arquitetos da cidade passava como colega desconhecido. Como engenheiro não tinha ido além de geógrafo", em uma explícita referência à formação de d'Ave na Politécnica.
\end{abstract}

\title{
FONTES PRIMÁRIAS
}

Arquivos Privados Arquivos da família Guinle de Paula Machado.

Arquivo da família Porto d'Ave.

Arquivos

Institucionais

Arquivo da Casa de Oswaldo Cruz - Fundo Coleção Monumento a

Oswaldo Cruz/Série Fundação Oswaldo Cruz (FOC)

Biblioteca da Academia Nacional de Medicina (BANM) -

Boletim da Academia Nacional de Medicina

Seção de Protocolo da Escola Politécnica. Centro de Tecnologia da

Universidade Federal do Rio de Janeiro

\section{REFERÊNCIAS BIBLIOGRÁFICAS}

Ackerknecht, Erwin

1986

Almanak Laemmert. 1919 a 1927

Anelli, R. et alii 2001

Araújo, Oscar da Silva 1927

Barros, Geraldo M.

Guilherme Guinle

1982

Benchimol,

Jaime L. (coord.)

1990

Bittencourt, Tânia

Mara Motta

1998

Brasil

1956

Brasil

1930
La médecine hospitalière à Paris, 1794-1848.

Paris, Payot.

Rio de Janeiro, Ed. Laemmert.

Rino Levi: arquitetura e cidade. São Paulo, Romano Guerra Editora.

'A prophylaxia da lepra e das doenças venéreas no Brasil e a actuação do Departamento Nacional de Saúde Pública'. Archivos de Hygiene. Rio de Janeiro, ano I, no II, pp. 195-293.

Rio de Janeiro, Agir.

Manguinhos do sonho a vida - a ciência na Belle Époque. Rio de Janeiro, Casa de Oswaldo Cruz/Fiocruz.

Arquitetura sanatorial São José dos Campos. São José dos Campos, SP.

Mensagens ao Congresso: obras completas de Epitácio Pessoa. Vol. XVII. Rio de Janeiro, INL.

Mensagens ao Congresso: Washington Luiz P. de Sousa. Rio de Janeiro, Imprensa Nacional. 
Brasil

Cardoso, Vicente Licínio 1927

Carvalho, Marta

Maria Chagas de 1998

Chagas Filho, Carlos 1993

Czajkowski, Jorge (org.) 2000

Foucault, Michel

1977

Hochman, Gilberto 1998

Marinho, João 1931

Miquelin, Lauro Carlos 1992

Morínigo,

Fábio Cupertino abril-junho 2001

Murken, Axel Hinrich abril 1994

Nascimento, Dilene

et alii. fev 2002.

Nascimento, Dilene 2002

Porto d'Ave, A. ago. 1928

Porto d'Ave, A.

1927

Porto d'Ave, A. jan.-fev. 1928

Risse, Guenter1 1999

Santos, Sydney dos s. d.

Telles, Pedro Carlos da 1984-1993
Mensagens ao Congresso: Arthur da Silva Bernardes.

Rio de Janeiro, Imprensa Nacional.

A margem da arquitetura grega e romana e princípios geraes modernos de hygiene hospitalar. Rio de Janeiro, Typographia do Anuário do Brasil.

Molde Nacional e fôrma cívica: higiene, moral e trabalho no projeto da Associação Brasileira de Educação (1924-1931). Bragança Paulista, Edusf.

Meu pai

Rio de Janeiro, Casa de Oswaldo Cruz/Fiocruz.

Guia da arquitetura eclética no Rio de Janeiro.

Rio de Janeiro, Centro de Arquitetura e Urbanismo.

O nascimento da clínica.

Rio de Janeiro, Forense Universitária.

'Logo ali, no final da avenida: os sertões redefinidos pelo movimento sanitarista da Primeira República'. História, Ciências, Saúde-Manguinhos, vol. 5 (supl.), pp. 217-35.

Ocasião perdida - depoimento prestado perante a Comissão de Sindicâncias da sobras do Hospital das Clinicas. Rio de Janeiro, Oficina Industrial Graphica.

Anatomia dos edifícios hospitalares.

São Paulo, Cedas.

'Dos primórdios ao HSE'.

Revista Médica HSE, vol. II, nº 35 .

'The church hospital and the municipal hospital in Germany from the Biedermeier period to the Weimar Republic'. Planning Perspectives, vol. IX, nº II.

O sanatório de Curicica. Uma obra pouco conhecida de Sérgio Bernardes. Arquitexto 26.02. In www.vitruvius.com.br.

Fundação Ataulpho de Paiva — Liga Brasileira contra a Tuberculose: um século de luta. Rio de Janeiro, FAPERJ/Quadratim.

'Sanatório Santa Clara - Campos do Jordão'. A Bandeira, no 11 , pp. 17-9.

'A Semana do Hospital - conferência do professor Carlos Seidl em 29 de marco de 1928 - o que os outros têm e nós não temos'.

A Bandeira, ano II, n으 9-10, pp. 18-24. mar.-abr. 1928

'O hospital moderno'. A Bandeira.

Rio de Janeiro, ano I, nº 1, julho, pp. 24-30.

'A Fundação Gaffrée e Guinle'.

A Bandeira, ano II, nos 7-8, pp. 8-14.

Menging bodies, saving souls - a bistory of hospitals.

Nova York/Oxford, Oxford University Press.

O legado de Vicente Licínio Cardoso - as leis básicas da filosofia da arte. Rio de Janeiro, Editora da UFRJ.

História da engenharia no Brasil.

Rio de Janeiro, Clavero Editoração.

Recebido para publicação em maio de 2003. Aprovado para publicação em janeiro de 2004. 